Para citar este artículo / To cite this article:

HAMLIN, Cinthia María, \& Ludmila GRASSO (2022), "Los poemas en arte mayor castellano de Les trobes en lahors de la Verge Maria $(74 * \mathrm{LV})$ : problemas ecdóticos, interferencias lingüísticas y edición crítica», Revista de Cancioneros Impresos y Manuscritos, 11, pp. 148-211. https://doi.org/10.14198/rcim.2022.11.04

\title{
LOS POEMAS EN ARTE MAYOR CASTELLANO DE LES TROBES EN LAHORS DE LA VERGE MARIA (74*LV): PROBLEMAS ECDÓTICOS, INTERFERENCIAS LINGÜÍSTICAS Y EDICIÓN CRÍTICA THE CASTILIAN ARTE MAYOR POEMS OF LES TROBES EN LAHORS DE LA VERGE MARIA (74*LV): ECDOTIC PROBLEMS, LINGUISTICINTERFERENCES, ANDCRITICAL EDITION
}

Cinthia María Hamlin

SECRIT (CONICET)/Universidad de Buenos Aires, Argentine cinthiahamlin@conicet.gov.ar

https://orcid.org/0000-0002-2194-0814
Ludmila Grasso

Universidad de Buenos Aires, Argentine grasso.ludmila@hotmail.com https://orcid.org/0000-0002-7107-9292

El trabajo que aquí presentamos no podría haberse realizado sin la gentil ayuda de quienes, en el contexto de aislamiento del último año, nos hicieron llegar bibliografía indispensable, respondieron a nuestras consultas o leyeron diversas versiones de estas páginas. Nuestro sincero agradecimiento a Vicenç Beltran, Antoni Biosca Bas, Laura Fernández Fernández y Arístides Gil Fatás.

Cinthia Hamlin dirigió la investigación, se encargó de los apartados 1, 2.2 y redactó junto a Ludmila Grasso el 2.1. Ambas coparticiparon en el análisis de las interferencias y las búsquedas en corpus digitales; mientras Grasso se encargó de las notas de historia de la lengua, tanto en 2.1 como en la edición crítica, Hamlin editó los poemas, a partir de una primera transcripción hecha por Grasso. De ahí el orden de firma.

\section{RESUMEN}

En este artículo estudiaremos los dos poemas en arte mayor castellano que se transmiten en Les trobes en lahors de la Verge Maria: "Del gran Redemptor» ([ID 4650] de Francí de Castellví y "Al tempo que Febo» ([ID4652] de Pere de Civillar. Analizaremos sus características métricas y estróficas para luego desarrollar las diversas problemáticas ecdóticas que encierran. Nos detendremos, asimismo, en un estudio de sus interferencias lingüísticas, cuya identificación no solo es fundamental para realizar una edición crítica respetuosa del diasistema del texto, sino que nos permitirá también 
avanzar hipótesis sobre los diferentes procesos lingüísticos, compositivos y mecánicos que entran en juego durante los procesos de composición poética y de impresión, así como sobre la procedencia de los agentes involucrados. Ofreceremos, finalmente una nueva edición crítica de ambos poemas.

PALABRAS CLAVE: arte mayor; Les trobes en lahors de la Verge Maria; praxis ecdótica; interferencia lingüística; edición crítica

\section{ABSTRACT}

In this paper we study the two Castilian arte mayor poems that are transmitted in Les trobes en lahors de la Verge Maria: Francí de Castellvís "Del gran Redemptor» ([ID 4650] and Pere de Civillar's "Al tempo que Febo» ([ID4652]. In the first part of the paper, we describe the prosody of these poems (stanza and meter), which will offer a proper framework for text editing. In the second part, we consider linguistic interference. Identifying Catalan and Aragonese influences will allow us not only to approach a critical edition in a way that respects the text's diasystem, but also to reflect on the linguistic, compositional and mechanical processes that take part during the poetic composition and the printing process. Finally, we hereby publish a new critical edition of both poems.

KEYWORDS: arte mayor; Les trobes en lahors de la Verge Maria; ecdotic problems; linguistic Interference; critical edition 
Les trobes en lahors de la Verge Maria $\left(74^{*} L \mathrm{~V}\right)$ se transmite en un testimonio único que se conserva en la Biblioteca Universitaria de Valencia (signatura CF/1) y fue considerado, por mucho tiempo, el primer incunable español. ${ }^{1}$ Es bien sabido, asimismo, que tuvo origen en el certamen poético que Lluís Despuig organizó en 1474 en honor a la Virgen María. ${ }^{2}$ Poetas de diversos círculos y estratos sociales participaron en la convocatoria que, a través de un cartell de la pluma del poeta mosén Bernat Fenollar, instaba a alabar a la Virgen en cualquier lengua o estilo. ${ }^{3}$ El cancionero resultante, de carácter plurilingüe de acuerdo a los lineamientos de Pérez Bosch (2005: 363), transmite 45 poemas: uno en italiano, cuatro en castellano y el resto en catalán. ${ }^{4}$ Nos detendremos en este trabajo en dos de estos poemas castellanos, «Del gran Redemptor» ([ID 4650], de aquí en adelante DGR) de Francí de Castellví y «Al tempo que Febo» ([ID4652], de aquí en adelante ATF) de Pere de Civillar, los cuales se ajustan al esquema del arte mayor.

1 Les trobes en lahors de la Verge María, Valencia, Lambert Palmart, 1474. LV ha sido editado por Martí Grajales (1894), Guarner (1974), Sanchis Guarner (1979) y Ferrando Francés (1983: 157-344). Además de la catalogación de Dutton (1990-1991), véase BETA manid 2724 (Philobiblon), ISTC im00270500, GW M27366; H 6966; Haeb(BI) 488; Vindel(A) III 3: 1; IBE 4158. Recién en 1930 se descubre el Sinodal de Aguilafuente (Segovia, 1472), considerado en la actualidad el primer incunable de la Península (Reyes Gómez, 2005: 59). Sin embargo, tal como lo hicieran Guarner (1974: 18) y Sanchis Guarner (1979: 47-58), Reyes Gómez considera a LV el primer incunable de carácter literario (2015: 68); mientras que recientemente Martos lo identifica como el primer incunable poético (2021). Excepto en los dos poemas que analizaremos aquí, el resto de las citas de LV corresponden a Sanchis Guarner (1979). Las cursivas serán siempre nuestras.

2 Respecto de Lluís Despuig, su devoción mariana y la organización de certámenes, véase Sanchis Guarner 1979: 10 y Ferrando Francés 1983: 157.

3 Así reza el cartell: «(Vin)gau hi tots, senyors, per aquell (dia)/ honrant, si us plau, tan bella siti(ada),/ en cobles cinch, endereça o torn(ada),// lengua y estil lo que plasent vo(s sia)», (4ad). En relación al status socio-cultural de los poetas véase Guarner 1974: 31, Sanchis Guarner 1979: 14 y Ferrando Francés 1983: 167-168.

4 El cancionero transmite, en realidad, 47 composiciones. La primera es el "cartell», la cual no suele ser numerada en las ediciones. La última, que suele recibir el número 46 , es en realidad el veredicto del certamen, escrito también por Fenollar. Sobre el uso del castellano en $L V$, así como su creciente prestigio y penetración en la aristocracia valenciana, véase Sanchis Guarner 1979: 13-14 y Ferrando Francés 1982: 113-114. 
Pérez Priego ha destacado varias de las problemáticas específicas que conlleva editar un testimonio único, entre las que subraya la dificultad que puede surgir a la hora de detectar errores o anomalías, pero sobre todo en la fase de enmendatio, dado que el editor no puede acudir a la selectio de variantes. Por estos motivos, advierte (2012: 426):

Es muy importante entonces conocer con la mayor precisión posible lo que en sentido amplio llamaríamos el usus scribendi y los pasos y peculiaridades de la tradición. Es decir, conocer muy bien el uso lingüístico de la obra y de la época, las particularidades dialectales, el uso estilístico y métrico del autor y del género, las características del manuscrito conservado. ${ }^{5}$

Conde (2002: 266), en su estudio sobre praxis ecdótica y arte mayor, hizo una advertencia similar: la importancia de conocer en profundidad tanto el verse pattern del texto, como el sistema lingüístico en el que se inserta y participa. En el caso de nuestros dos poemas, de hecho, sus problemas ecdóticos, acentuados por su carácter de testimonio único, se hallan íntimamente ligados no solo a la naturaleza versal, tan artificial como dúctil, del arte mayor, es decir, a su «verse design» (Lázaro Carreter 1972: 350), sino también al complejo contexto enunciativo del que emergen. Por un lado, mientras que el poema $D G R$ fue compuesto por un poeta valenciano - Francí de Castellví-, el poema ATF lo compone un poeta de origen incierto -Pere de Civillar-, acaso castellano. ${ }^{6}$ Es menester aclarar que el castellano que poetas bilingües como

5 La problemática de la edición crítica de poesía transmitida en testimonios únicos ha sido objeto de un reciente monográfico coordinado por Martos (2017), el cual ofrece un panorama representativo de las tradiciones poéticas más importantes de la Península (castellana, catalana y gallego-portuguesa) a través del estudio de casos concretos.

6 Respecto a la procedencia de los contendientes, Martí Grajales (1865: 66) y Ferrando Francés (1983: 202) sostienen la dificultad de afirmar con certeza el origen del argenter Pere de Civillar, si bien se inclinan a considerarlo castellano. Distinto es el caso del noble Francí de Castellví: dado su estamento, no solo se encuentra documentado, sino que se sabe de su labor para la corona aragonesa (Ferrando Francés 1983: 173-4). Rubio (2020: 170-174), en un reciente estudio sobre los Castellví al que reenviamos para más detalles sobre la vida del poeta, señala: «en 1464 era nombrado camarero del primogénito Fernando, el futuro rey Católico, y más tarde mayordomo del monarca». Añade Rubio que 
Castellví utilizaban en la corte, como resumiremos más adelante, tiene una marcada influencia del aragonés, lo cual complica el panorama lingüístico-enunciativo. Por otro lado, ambos poemas castellanos forman parte de un cancionero mayoritariamente catalán, salido de una imprenta valenciana que, como apunta Ferrando Francés (1999: 122), probablemente fue objeto de una corrección regularizadora de rasgos gráficos y morfológicos por parte de su curador, Fenollar.

En efecto, más allá de las posibles interferencias lingüísticas que los poetas, como en todo contexto de lenguas en contacto, pueden incorporar durante el proceso de composición - consciente o inconscientemente, como ya veremos-, es necesario tener en cuenta las interferencias que posiblemente se introdujeron también en el proceso de impresión. El componedor, más allá de cometer errores mecánicos propios de la imprenta, cuando lee y copia el modelo se comporta, como es sabido, como un copista: comete el mismo tipo de errores (Pérez Priego 1997: 27-28), a la vez que tiende a introducir variaciones acordes con su sistema lingüístico. En este sentido, el concepto de Segre de «diasistema» puede aplicarse perfectamente a la primera época de la imprenta:

I copisti medievali lavorano di solito fra due poli d'attrazione: lo sforzo di rispettare l'esemplare da cui copiano, e la tendenza a seguire le proprie abitudini linguistiche. [...] In dialettologia, il termine diasistema [...] designa o il supersistema a cui si possono riferire due sistemi affini, oppure il sistema di compromesso tra due sistemi in contatto. Mi pare che il mélange linguistico rappresentato dalle trascrizioni medievali costituisca un tipo particolarmente sviluppato e interessante di diasistema, nella seconda delle accezioni elencate. [...] Nel caso più semplice, il diasistema sarà il risultato del compromesso tra il sistema del testo (S1) e il sistema del copista (S2): D = S1+ S2. Ma a sua volta la copia verrà trascritta da un altro copista, col suo sistema (S3), per cui si avrà: $\mathrm{D}=$ S1+ S2 + S3, e cosí via (1979: 58).

posiblemente sea por su lealtad a la corona durante la guerra con Cataluña que fue elevado su rango al de noble. 
En el caso de $D G R$ y ATF tenemos el sistema del texto (S1: castellano), que difiere del sistema lingüístico del poeta, al menos en $D G R$ (S2: catalán, en su variedad valenciana), y del sistema del componedor (S3: ¿también valenciano?). Siguiendo los postulados de Ferrando (1999) acerca del papel que habría jugado Fenollar en cuanto editor y «normalizador» de ciertos rasgos lingüísticos, tendríamos que incluir también el sistema del editor (S4). ${ }^{7}$ Dado este complejo diasistema, coincidimos con la conclusión a la que llega Segre: el concepto de «reconstrucción» (i.e. la constitutio textus) resulta un tanto "primitivo» y solo debe aplicarse cuando sus resultados fueran incontrovertibles - conscientes de que serán parciales y experimentales-.

Hechas estas salvedades, solo queda puntualizar que en las últimas ediciones de Les trobes - Sanchis Guarner (1979) ${ }^{8}$ y Ferrando Francés (1983) - tanto DGR como ATF han sido objeto de varias enmiendas que no siempre tienen en cuenta el verse pattern, ni el sistema lingüístico del poeta o del componedor, ni el diasistema del texto. En el análisis que haremos a continuación relevaremos tanto estos casos como otros que, siendo anómalos, no fueron detectados ni enmendados por los editores y requerirían, como mínimo, de una problematización. Nos detendremos, asimismo, en un estudio de sus interferencias lingüísticas, cuya identificación no solo es fundamental para realizar una edición crítica respetuosa del diasistema del texto, sino que nos permitirá también avanzar hipótesis sobre los diferentes procesos lingüísticos, compositivos y mecánicos que entran en juego durante los procesos de composición poética y de

7 En la introducción de su estudio sobre el papel de los editores en la fijación del catalán moderno, Ferrando Francés (1999: 113) advierte, por un lado, cómo el editor o el impresor solían manipular ciertos elementos de los textos para adaptarlos al gusto de los destinatarios y, por otro, cómo la reproducción en serie exigía cierta uniformidad de soluciones lingüísticas, para garantizar un mínimo de calidad textual.

8 Aunque Sanchis Guarner presenta su texto como una transcripción, los criterios que aplica en los poemas castellanos responden más a una edición crítica que a una transcripción: solo para mencionar dos ejemplos, véase cómo normaliza casos de interferencia lingüística —àngels (DGR, 2e), virgens $(A T F, 4 f)$ como ángeles y vírgenes (analizaremos estas posibles interferencias más adelante)-, y cómo decide editar la lección rosa espijada (DGR, 1c) como rosa espejada, para lo cual debió sí o sí aplicar su iudicium. Volveremos sobre estos casos. 
impresión, así como sobre la procedencia de los agentes involucrados. Ofreceremos, finalmente una nueva edición crítica de ambos poemas, conscientes de que la nuestra es simplemente una «ipotesi di lavoro» (Contini 1986: 74).

\section{EL ARTE MAYOR Y SUS PROBLEMAS ECDÓTICOS}

Características de las composiciones: estrofas, metro y licencias poéticas

Los dos poemas castellanos que nos competen tienen la particularidad de estar compuestos en coplas de 10 versos en arte mayor, que siguen la prototípica estructura de rima $A B A A B: C D C C D$ de la copla real, pero no el correspondiente patrón métrico octosílabo. ${ }^{9}$ En efecto, los versos de estas coplas tienen el mismo verse design (Lázaro Carreter 1972: 350; Conde 2002: 261), es decir, la misma andadura, patrón rítmico y sistema de reglas que los que se encuentran en la tan difundida copla de arte mayor castellana: en ambos casos se tratan de versos anisosilábicos e isorrítmicos, en tanto que, con una oscilación entre las 10 y las 13 sílabas métricas, siguen el rígido patrón rítmico (silábico-acentual) del adónico doblado óoo óo | óoo óo (Gómez Redondo 2017: 395-396). ${ }^{10}$ Ambas composiciones, además, están conformadas por 5 estrofas más una «tornada» en quintilla, según las pautas del certamen («en cobles cinch, endreça o tornada», 4c).

9 Para las características típicas de la copla real castellana, véase Valero Moreno 2016: 534-535 y el canónico artículo de Clarke (1942).

10 Véase para todo esto el trabajo de Navarro Tomás (1956), los clásicos de Balaguer (1954), Lázaro Carreter (1972), Duffell (1999) y, sobre todo, los de Gómez Redondo (2013: 65-66 y 2016: 490-9), quien puntualiza las diversas y encontradas discusiones que suscitó este verso y cuya línea de análisis seguimos aquí. Es de notar que, según Navarro (1956: 92), el verso de arte mayor puede variar entre las 10 y 14 sílabas, aunque señale que suele regularizarse en 12. Gómez Redondo (2013: 58), en cambio, señala que varía entre 8 y 12 sílabas: los casos de versos de 8 estarían compuestos por 2 hemistiquios de 4 sílabas fonológicas que terminan en términos agudos (oxítonos), es decir, se les incrementa una sílaba, convirtiéndose en hemistiquios de 5 sílabas métricas (2013: 63-64). En los casos de versos de 12 sílabas incluye aquellos cuya medida fonológica es mayor (13 o 14 sílabas), pero sufren un «decremento», sea por hemistiquio terminado en proparoxítona (2013: 65 y 2016: 492), sea en casos de compensación entre un hemistiquio y otro, sea en casos de sinalefa y sinafía, i.e., sinalefa que borra la cesura (2013: 65-6). Como señalaremos más adelante, en estos dos poemas no se registran versos de 14 sílabas fonológicas. 
La elección estrófica de la copla de diez versos en versos de arte mayor, como señala Valero Moreno (2016: 534), es infrecuente en la lírica castellana -Gómez Bravo (1999), por ejemplo, registra solo 12 casos, todas en el Cancionero General de Castillo, es decir, un cancionero valenciano- ${ }^{11}$ aunque no así en la catalana, donde se encuentra ampliamente registrada. ${ }^{12}$ Es muy probable, pues, que tanto el origen de los poetas como el sistema literario valenciano y sus modas haya influido en esta selección estrófica particular. En el contexto intratextual del incunable, de hecho, tenemos otras 13 composiciones catalanas en coplas de 10 versos con versos que responden al art major. Aunque están compuestas strictu sensu por decasílabos catalanes, ${ }^{13}$ este tipo

11 Tenemos 6 composiciones de una sola décima (ID [6509] 11CG-737; ID [6510] 11CG-738; ID [6553] 11CG-782; ID [6554] 11CG-783; ID [6562] 11CG-792; ID [6563] 11CG-793), dos composiciones con dos décimas (ID [6539] 11CG-768; ID [6540] 11CG-769) y dos con tres décimas (ID [6560] 11CG-790; ID [6561] 11CG-791). Todos estos casos responden al formato de preguntas y respuestas, igual que muchos de los poemas de LV. Las otras dos (ID [6062] 11CG-27 y ID [6063] 11CG-28) son composiciones de 5 décimas que se acercan a los poemas de nuestro incunable no sólo por la extensión, sino por la temática religiosa y encomiástica. Entre los autores de estas composiciones podemos destacar al Conde de Oliva, a Nicolás Castilla, Alfonso de Proaza, Salazar, Mossén Geroni Artés y Mossén Crespí de Valldaura. Hemos consultado el repertorio de Gómez Bravo (1999) en la base de datos online preparada por Escribano y Río Riande: http://www.digital-humanities.xyz/cancionero/.

12 En el Repertori mètric de Parramon i Blasco (1992) se registra en 51 composiciones (esquema 60).

13 El decasíl.lab catalán está conformado, en su formato clásico, por dos hemistiquios de 4 y 6 sílabas (- - - - || - . - - '), con acento obligatorio en cuarta y décima. Presenta una cesura luego del ictus en cuarta que, excepto pocas excepciones, cae forzosamente en término agudo (cesura masculina). El acento obligatorio en décima puede caer en término agudo o grave, en cuyo caso se omite la sílaba postónica del cómputo silábico. De las trece composiciones en décimas mencionadas, las que responden a este formato son los números 13 (Joan Verdanxa), 19 (Narcís Vinyoles), 21 (Joan Llançol), 22 (Genís Fira), 23 (Miquelot Pèreç), 30 (Lluís Català), 34 (Joan del Bosch), 37 (Bernat Despuig), 41 (Mateu Esteve) y 42 (Pere Alcanyís). El segundo formato, según Oliva (1986: 61-2) y Serra i Baldó (1932: 47), es el de 5+5, con acento en quinta y décima: números 9 (Joan de Nàjera), 20 (Joan Sobrevero) y 36 (Lluís Garcia). Como en el caso anterior, el ictus puede caer en término grave, en cuyo caso se omite la sílaba postónica: - - - - -' (-) || - - - - ' (-). Baldó señala que este formato de decasill/lab, cuyo origen es el verso de arte mayor castellano, se usa específicamente en Valencia, lo cual ejemplifica con LV. Para más precisiones (y excepciones) sobre el decasíl·lab catalán véase Oliva 1986: 61-2 y Serra i Baldó 1932: 39-42. Nótese que a este tipo de decasílabo de formato 5+5 responden también las composiciones 28 (Bartomeu Salvador) y 39 (Jeroni Monçó), conformadas no por décimas, sino por octavas de rima $A B B A: C D D C$. En este sentido, estas composiciones responden más ajustadamente al arte mayor. 
de verso tiende de forma natural a una combinación de dáctilo más troqueo como la del arte mayor castellano, lo cual se da aquí en todos los casos. ${ }^{14}$ De estos poemas, de hecho, el no 20 responde a un típico verso de arte mayor de derivación castellana, ${ }^{15}$ como aquellas coplas de 10 versos del Cancionero General. Teniendo en cuenta que el incunable está conformado por 45 composiciones, el hecho de que el 33,3\% (las 13 en catalán más las dos en castellano) respondan a coplas de 10 versos en arte mayor ya da la pauta de cuán extendida estaba en el sistema literario valenciano esta particular combinación de verso y estrofa.

Ambas composiciones castellanas, como ya dijimos, siguen el esquema silábicoacentual del arte mayor que, según las definiciones más usuales, suele variar entre las 10 y las 14 sílabas fonológicas, con tendencia a regularizar en doce. En efecto, DGR tiende a un metro más regular: en 55 versos, tenemos 52 que presentan doce sílabas métricas, ${ }^{16}$ dos casos de once sílabas (2j, 5a) y otro de trece, pero que es anómalo en su patrón acentual (2f). Otra particularidad es que, aunque en el arte mayor el primer ictus del verso puede caer tanto en primera como en segunda sílaba $-\mathrm{y}$ con menor

14 Vicenç Beltran (2002: 251-264) ha ya puntualizado, respecto de la composición de Pero Vélez de Guevara «Sancha Carrillo: si voso talante», la posibilidad doble de escandir sus versos como decasílabos -en su caso, trovadorescos gallegos - o como versos de arte mayor. El caso de nuestras trece composiciones es similar pues, las que responden al formato de $4+6$, además de los ictus obligatorios en 40 y 10 , presentan siempre acentos secundarios en 10 y 70 , mientras que las de $5+5$, además del acento principal en 50 y 10 으, reciben en 20 y 70 . En todos los casos responden, por tanto, al patrón óoo óo del arte mayor. Asimismo, escandiendo a la manera castellana, es decir computando sílabas postónicas y agregando una sílaba en finales de hemistiquio oxítonos, vemos que la mayoría se ajusta a un verso de 12 sílabas métricas. Aprovechamos para agradecer a Vicenç Beltran sus iluminadores comentarios sobre estas composiciones catalanas.

15 Nos referimos al poema de Sobrevero («Perquè lloar puga vostra senyoria»), cuyos primeros hemistiquios son siempre paroxítonos, como es común en el arte mayor castellano y más raro en los decasílabos catalanes. La mayoría de sus versos, escandiendo a la manera castellana, responden al patrón rítmico de 6+6 ( o óoo óo || o óoo óo), aunque algunos se ajustan a los otros dos formatos más usuales del arte mayor (Gómez Redondo 2016; 499): 6+5 (1b, 2e, 5c) y 5+6 (1f). Escandiendo a la manera catalana, sin embargo, son todos decasílabos.

16 Preferimos no utilizar la nomenclatura «dodecasílabo» o "endecasílabo» pues, según advierte Gómez Redondo (2016: 491), no resulta del todo apropiado referirse a un verso isorrítmico de esta manera. 
frecuencia en tercera-,${ }^{17}$ en esta composición, excepto un verso que lo recibe en primera sílaba («ángeles mil...», 2j), el ictus cae siempre en la segunda. Esta aparente regularidad, sin embargo, impone mayor constricciones a la hora de adecuar el material lingüístico al patrón aún más rígido o óoo ó[o] (en el caso de terminación oxítona) y solo es posible gracias a diversos metaplasmos propios del arte mayor que, aunque se utilizan en toda la composición, aparecen con mayor frecuencia en los primeros hemistiquios: nos referimos a la dislocación acentual, sea sístole o éctasis («es querer fundar...», 1j; "y_antes que nasciesses...», 2b; "y jamás cessaron...» 2g, obsérvese también en $3 \mathrm{ac})^{18} \mathrm{y}$ al ictus en monosílabo átono ("si mi lengua_estando...», 1g; "luç de la qual sabes...», 4f y sig., "tú la melezina...», 5h). Igualmente, son muchísimas más las licencias y/o metaplasmos que se aplican para adecuar el material al rígido patrón rítmico. En DGR se observan también: atonicidad de palabras situadas entre dos ictus (ciprés y lengua en los siguientes hemistiquios: "palma cipres flor...», 3a; "si mi lengua_estando...», 1g), contracciones que tienen origen en sinalefas ("...mas nunqua I' acabo», 1h; «Viendo 'I creador...», 3j), dialefa («...madre | hi esposa» 1a; «Qu'enprender lo | arte... », 1i), diéresis («...patrïarcas profetas», 2j) y apócope («que todo I' restante...», 2i). La compensación acentual en la zona de cesura es frecuente, aunque solo se registra el caso del segundo hemistiquio con ictus en tercera sílaba cuando el primer hemistiquio finaliza en oxítona (1j, 2a, 2j, 3a, 3j, 4a, 4j, 5a, 5j, 6a, $6 f):{ }^{19}$

17 Véase Conde 2002: 262. Como ejemplo de primer ictus en 3o puede verse en ATF los versos $2 \mathrm{~d}$ y $2 \mathrm{~h}$. 18 En estos y los subsiguientes ejemplos utilizamos itálicas para marcar el ictus, guión bajo para marcar sinalefas y barra vertical para separar sílabas cuando sea necesario. Cuando transcribimos solo un hemistiquio, los tres puntos antes o después indican si se trata del primero o el segundo. Ténganse en cuenta que solo señalamos algunos ejemplos paradigmáticos, pues los casos suelen ser numerosos. 19 Como se puede observar, estos casos se dan siempre en el primer y último verso de la estrofa (excepto en 1a: aunque el primer hemistiquio finaliza en oxítona, recibe el ictus siguiente en 2da). La decisión de conformar regularmente primer y último verso con final de hemistiquio oxítono difícilmente sea casual: se trata de una evidente decisión estilística, acaso motivada por una intención de acercar los versos al patrón del decasílabo catalán, cuyo primer hemistiquio finaliza siempre en término oxítono. El caso del verso 6a podría ser ambiguo, dada la posible doble escansión: 1- de| los | pa|triar|cas || de|se|a|da 
Que |vie|ra| des|pués || el| gran| e|van|ge|lis|ta o óoo ó[o] || eo òoo óo (4a) Pues| o|tri| de|sir || no| po|drí|a| qual| e|res o óoo ó[o] || øo óoo óo (4j)

La presión del esquema métrico determina, a nivel léxico, ciertas incoherencias en el sistema lingüístico que se producen también con la intención de ajustar el contenido y su material lingüístico al verse design: nos detendremos en ellas más adelante.

En ATF, en cambio, los versos de 11 sílabas -medida que, según Gómez Redondo (2016: 499), es una de las más comunes del arte mayor- ascienden en frecuencia. En 55 versos tenemos 17 que se ajustan a este metro: 14 en sus variantes más usuales de $5+6$ y $6+5$, dos con sinafía ( 1 b y $1 \mathrm{~h}$ ), y uno que resulta anómalo al patrón rítmico (1f)..$^{20}$ Los versos de once sílabas, por tanto, representan un 30,9\% del total, porcentaje cercano al de la incidencia que, según Navarro Tomás (1956: 92-3), tiene este metro en el Laberinto de la Fortuna (29\%). En este caso, además, la caída del primer ictus de cada verso varía según las posibilidades que ofrece el arte mayor -entre primera y segunda sílaba mayoritariamente-, lo cual repercute en una mayor adecuación entre acento rítmico y acento gramatical del término o, lo que es lo mismo, en una menor frecuencia de metaplasmos y licencias, que se reducen a casi la mitad con respecto a la composición anterior. ${ }^{21}$ Además de presentar, en menor medida como ya dijimos, los que señalamos para $D G R$ - dislocación acentual («...vienes de la vit», 4c), ictus en monosílabos («de» en $2 \mathrm{~d}$ y «la» en $4 \mathrm{f}$ ), atonicidad de término entre dos ictus («cierto» en $3 \mathrm{~g}$ ), contracciones (1h, 2b) y dialefa («...hi | escuredat», 1c; «de

|es|tre|lla (sístole en patriarcas y dialefa da-es) y 2-de| los| pa|triar|cas || de|se|a|da_es|tre|lla (el 2 do hemistiquio también podría tener una sinéresis entre e y $a$ «de|sea|da| es/tre|lla»). Advertida la tendencia regular del primer y último verso de cada estrofa a presentar un primer hemistiquio oxítono con primer ictus en 20 , nos inclinamos por la primera posibilidad de escansión.

20 Además de dos versos de 10 sílabas ( $4 \mathrm{f}$ y $5 \mathrm{~h}$ ), tenemos un verso de 13 sílabas ( $2 \mathrm{~h}$ ). El total de versos de 12 sílabas, por tanto, es de 35. Nos dedicaremos a los versos anómalos más adelante.

21 Mientras que en DGR hemos contado 35 metaplasmos, en ATF sólo tenemos 16 - hemos contado solamente casos de dislocación acentual, dialefa, diéresis, sinafía y términos átonos acentuados-. 
| antigüidat», 1d)—, se observan también casos de diéresis («Sabor y scï|entia...», 3h; «amado, fï|el...», 6c), sinafía ("fue demostrada | en el centro profundo», 1b; 1h) y varios polisílabos que reciben dos ictus («...hi escuredad», 1c; «...de consolación», 3a; «inmaculada...», 3a; «...sabidoría», 3i -en estos últimos dos casos el polisílabo ocupa todo el hemistiquio-). ${ }^{22}$ Las compensaciones son menos frecuentes que en DGR, aunque del mismo tipo 23 - segundo hemistiquio recibe ictus en tercera cuando el primero culmina en término oxítono-:

De |cer|to| que|dó || en |las |par|tes| del| mun|do o óoo ó[o] || ఠo óoo óo (1e) De| tal| cla|ri|dat || que| li| die|re| el| cie|lo o óoo ó[o] || өo óoo óo (2j)

Este caso de compensación no es obligatorio: los finales de hemistiquio

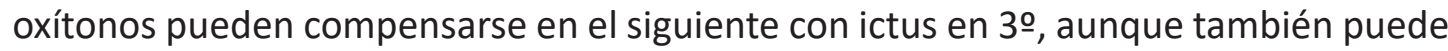
aceptarlo en 2ㅇ, como aclara Conde (2002: 262) y demuestra este poema en varios versos (1j, 3f, 4f, 4h, 6b).

Es interesante mencionar que se dan en este poema tres casos de un primer hemistiquio paroxítono seguido de un segundo hemistiquio que recibe su primer ictus en primera sílaba:

$$
\begin{array}{ll}
\text { y| po|ne 'n| las } \mid \text { gen|tes || sa|bi|do|rí|a } & \text { o óoo óo || òoo óo (3i) } \\
\text { de| to|dos| lo|ha|da || los| che|ru|bi|nes } & \text { o óoo óo || òoo óo (5g) } \\
\text { se|rá |por| me|mo|ria || fas|ta_a| los|fi|nes } & \text { o óoo óo || òoo óo (5j) }
\end{array}
$$

Aunque, Lázaro Carreter (1972: 352) sostenía la «ley» según la cual, en condiciones normales -es decir, primer hemistiquio paroxítono-, el segundo

22 Para los diversos metaplasmos o licencias que se utilizan en del arte mayor, véanse Gómez Redondo 2016: 490 y Lázaro Carreter 1972: 356-364.

23 No incluimos los casos de versos con interferencias lingüísticas (àngels, $2 \mathrm{~d}$ y virgens, 4f), las cuales tanto Ferrando Francés como Sanchis Guarner normalizan, generando versos que sí requieren compensación. Como argumentaremos más adelante, en estos casos conservamos el texto como se transmite en el incunable. 
hemistiquio recibe su primer ictus siempre en segunda sílaba, Gómez Redondo (2013: 62-63, 65, 68-69) cita muchos versos - algunos extraídos de los ejemplos artificiales que da Nebrija en su Gramática y de otros muchos poetas del s. $\mathrm{XV}-{ }^{24}$ en los que bajo las mismas condiciones rítmicas se repite esta dinámica de segundo hemistiquio con primera sílaba tónica, la cual no resultaba por tanto tan inusual. Refiere explícitamente a este problema cuando, respecto del verso de la Comedieta de Ponza «e | gran|des | po|de|res || son| per|pe|tua|les» (o óoo óo || óoo óo v. 4), señala: «[e]s cierto que la cadencia del primer hemistiquio puede imponerse sobre el período del segundo ("son| per|pe|tü|a|les", o òoo óo), pero la otra opción es también admisible, al igual que en este caso de la misma copla: "e | có|mo| For|tu|na || es| su|pe|rio|ra" (v. 6)» (2013: 69). A la hora de editar, sigue Gómez Redondo, es fundamental tener en cuenta este esquema "para no forzar resoluciones con diéresis en versos que se podrían acomodar al molde del pentasílabo». Este es el caso de los siguientes versos, cuyos segundos hemistiquios podrían recibir ictus en segunda sílaba postulando diéresis en sus términos finales (püesta; perfectión) pero que, sin embargo, se ajustan al molde del pentasílabo destacado por Gómez Redondo:

$$
\begin{aligned}
& \text { en | un }|c a| \text { rro| triun|fan|te || } m u \mid \text { txo| bien| pues|ta } \quad \text { eo óoo óo || óoo óo (2d) } \\
& \text { Tú| de las| vir|gens } \quad|| \text { la| per|fec|tión } \\
& \text { es|ta_en|tre| to|das || la| per|fec|tión } \\
& \text { óoo óo || òoo ó[o] (4f) } \\
& \text { óoo óo || òoo ó[o] (5h) }
\end{aligned}
$$

Dado que el mismo esquema rítmico se da en otros tres versos ( $3 i, 5 g, 5 j)$, en este caso específico no quedan dudas de que la opción editorial sin diéresis es la más adecuada. No solo es fundamental, como profundizaremos en el próximo apartado, conocer las diversas posibilidades rítmicas que el esquema métrico avala, sino también sus excepciones más frecuentes, pues evita que se cometan errores en

24 Pueden encontrarse este tipo de versos en diversas citas a lo largo del estudio de Gómez Redondo (2013): casos de la Gramática, en las pp. 63-64, casos el Laberinto de la Fortuna, el Cancionero de Baena y la Comedieta de Ponza en pp. 65, 68 y 69. 
la constitutio textus. No nos referimos tanto a estos casos de posible diéresis, ${ }^{25}$ sino a forzamientos más radicales, como la aplicación de una enmienda ope ingenii. En efecto, si evaluáramos los tres casos anteriores $(3 \mathrm{i}, 5 \mathrm{~g}, 5 \mathrm{j})$ desde la ley de Lázaro Carreter serían hipométricos y una enmienda de este tipo estaría avalada. Los numerosos casos de versos con este patrón rítmico, sin embargo, impiden concluir que se tratan de versos anómalos.

Decisiones y problemas en la «constitutio textus» según el «verse pattern»

Ya señalamos cómo Conde (2002: 266), en su lúcido estudio sobre la praxis ecdótica y arte mayor, destacaba cuán importante es conocer en profundidad tanto el verse pattern del texto, como el sistema lingüístico en el que se inserta y participa. En efecto, la presión que ejerce el rígido esquema silábico acentual del arte mayor trae consecuencias a nivel lingüístico (Conde 2002; Lázaro Carreter 1972): con el objetivo de ajustar su material a la armazón rítmica del verso, el poeta suele aprovechar ya sea la «forma vacilante» (Lázaro Carreter 1972: 361) de ciertos vocablos -eligiendo, de acuerdo con el caso, la que más se ajuste a su necesidad - ya sean formas ajenas a su sistema (Conde 2002: 264) o, como veremos en nuestras composiciones, formas que pertenecen a su sistema lingüístico, pero no al del texto. Así, en una misma composición suelen convivir distintas variedades o formas del mismo término. En la composición $D G R$, por ejemplo, el poeta utiliza tanto el arcaísmo $a n^{26}$ como el coetáneo ahun, según las exigencias de cada metro:

$$
\begin{array}{ll}
\text { Mejor de las buenas || y_an } \mid \text { de| las| me|jo|res } & \text { o óoo óo || o òoo óo (1e) } \\
\text { Del| fue |ras| a|hún || la| más| al|ta_y| lu|ci|da } & \text { o óoo ó[o] || øo óoo óo (6e) }
\end{array}
$$

\footnotetext{
25 De hecho, en DGR 2j hemos agregado una diéresis acaso no necesaria: «án|ge|les| mil || pa|trï|ar|cas| pro|fe|tas». En este caso, la tendencia rítmico-estilística que advertimos en este poema, a saber, el primer y último verso de cada estrofa presentan primer hemistiquio oxítono y segundo con ictus en tercera, a nuestro parecer justificaría una diéresis que acomode el verso al patrón.
}

26 Véase el Diccionario Medieval Español (de aquí en más DME) de Alonso 1986, s. v. an. 
Nótese, respecto del primer ejemplo, que mientras Ferrando Francés (1983: 260-261) respeta la lección an, señalando que está por aun, Sanchis Guarner (1979: 131) edita reponiendo la $u$. Esta opción podría, en términos métricos, explicarse aduciendo que aun funciona como un monosílabo («Me |jor | de | las | bue | nas || y_a(u) $\mathrm{n}$ | de las $\mid$ me $|j o|$ res»), pues aún con tilde diacrítica - como tenemos en el segundo ejemplo del mismo poema (6e) - convertiría el verso en hipermétrico ( Me $|j o r|$ del las | bue |nas || y a|(u)n| de| las| me|jo|res»). ${ }^{27}$ La enmienda que propone el editor genera, pues, una posible ambigüedad en la escansión que no estaba presente en el original. Es más, acaso sería factible preguntarse si el arcaico an no habría sido elegido por el poeta en lugar del aun justamente para evitar tal efecto. Cualquiera sea el caso, resulta poco económico enmendar cuando el verso era ya correcto.

En otras ocasiones el término utilizado, como puntualizaba Conde, pertenece a otro sistema lingüístico:

$$
\text { A |milga| de Dios || en| cel| si|glo| cre|a|da o óoo ó[o] || oo óoo óo (2a) }
$$

Tanto Sanchis Guarner como Ferrando Francés enmiendan la lección original cel - probable provenzalismo como sostendremos - con el («en el siglo»): ${ }^{28}$ aunque esta enmienda respeta el patrón rítmico, atenta contra el sentido del verso y la corriente doctrinal subyacente. En efecto, este verso leído en su contexto hace referencia a la Inmaculada Concepción:

27 Recuérdese que con un primer hemistiquio paroxítono (buénas), el primer ictus del segundo hemistiquio no puede caer en tercera sílaba (dé), véase Conde 2020: 262.

28 Sanchis Guarner señala la c entre paréntesis — «en (c)el siglo» (1979: 131) - : según las pautas que expresa en su introducción (1979: 62), esto indicaría que según su criterio se trata de una errata de impresión. Nótese que utiliza también el paréntesis para señalar sus agregados, como se veía en el ejemplo de " $a(u) n »$, pero también para sugerir sus omisiones, como aquí, lo cual da cuenta de un criterio editorial un tanto confuso. A esto habría que sumar que en varias ocasiones enmienda agregando una letra, sin señalarla con paréntesis: «viendo el Creador...» (3j, LV lee «viendol creador»); mientras que en otros casos similares (i.e. caída de vocal átona por sinalefa) no repone la vocal, sino que agrega un correspondiente apóstrofe: «...mas nunca l’acabo» (1i). 
Amiga de Dios en cel siglo creada

y antes que naciesses por Dios escogida,

nasciendo 'nel ventre, nuncha manzillada,

nasciendo 'nel mundo, muy glorifficada,

de todas virtudes toda guarnecida (2a-e).

Respecto al problema de si la Virgen nació o no con pecado original, se desarrolló desde c. 1129, cuando se restituye la fiesta de la Inmaculada Concepción por el Concilio de Londres, una controversia entre dos vertientes doctrinales escolásticas: los inmaculistas y los maculistas. A los simples fines de dilucidar nuestro locus, sintetizaremos muy someramente esta discusión teológica, harto compleja:29 mientras que para los maculistas la Virgen fue concebida en el vientre materno como el resto de la humanidad, es decir, con pecado, y luego fue inmediatamente santificada y desprovista de él, para los inmaculistas la Virgen fue elegida y creada antes de la creación del mundo y, por tanto, de Adán y su pecado. ${ }^{30}$ Twomey detalla cómo la doctrina inmaculista, junto a las imágenes de «pre-creación» asociadas a la prefiguración mariana de Proverbios $8.22-4,{ }^{31}$ presentan un registro vernacular

29 Dado que la bibliografía es abundantísima, para una profundización reenviamos al estudio de Twomey (2008: 23-42) pues, además de repasar el desarrollo de la controversia, el pensamiento de sus máximos exponentes y reenviar a la bibliografía precisa, se centra en cómo se desarrolló la discusión en los reinos de Castilla y Aragón.

30 Para más precisiones véase Twomey 2008: 47, quien además aclara: «Debate over the doctrine was responsible for polarizing theological opinion across Europe [...]. The exile of Nicholas Eymerich from Aragon in the late fourteenth century shows that the controversy, which had begun as a scholastic debate, had become more politicized and more acrimonious». Antes señalaba: "By the early fifteenth century in the kingdom of Aragon, loyalty to the state was bound up with acceptance of the Immaculate Conception» (2008: 40).

31 Una de las prefiguraciones marianas del Antiguo Testamento es aquella de la creación de la Sabiduría, presente en Proverbios 8, 22-4 («Dominus possedit me in initio viarum suarum, antequam quidquam faceret a principio. Ab aeterno ordinata sum et ex antiquis antequam terra fieret. Nondum erant abyssi, et ego iam concepta eram») y también aludida, en boca de Salomón, en el Libro de la Sabiduría 9, 9: «et tecum sapientia quae novit opera tua quae et adfuit tunc cum orbem terrarum faceres et sciebat quid placitum esset oculis tuis et quid directum in praeceptis tuis» (cursivas nuestras). Véase para todo esto Twomey 2008: 176-185. 
temprano en España en la cantiga de loor 180 de Alfonso X donde se lee "Ca Vella e, segund' a profecía / que Salamon foi dela profetar, / que ante do mundo foi todavía / criada, e que nunc' a de minguar» (vv. 13-6 Mettmann 1986: 193-4, cursivas nuestras). Para el siglo XV se encuentran ya muy difundidas en Castilla ${ }^{32}$ y mucho más ampliamente en Aragón (Twomey 2008: 195, ver también Ferrando Francés 1983: 166), como demuestra no solo la implantación de la fiesta y los certámenes en su honor, sino las mismas composiciones poéticas. ${ }^{33}$

En el caso de Castellví, a partir de sus versos «antes que nasiesses por Dios escogida» y «nasciendo nel ventre nuncha manzillada», puede deducirse fácilmente cómo se adhiere a esta doctrina, lo que se corrobora en su otra composición de $L V$ : "Déu vos ha (e)let, ans dels segles eleta, / és-vos devot i vós d' Ell molt devota», ( $n$ o 4, 5fg). ${ }^{34}$ Desde este punto de vista, resulta evidente cómo la enmienda "en el siglo creada» es problemática, dado que «siglo», desprovisto de demostrativos o de adjetivación, debe entenderse como sinónimo de mundo, de este mundo. ${ }^{35}$ En el resto

32 Puede verse «Canción a la Concepción de Nuestra Señora» (ID3363) de Gómez Manrique («Entre todas escogida / [...] en tal noche conçebida, / antes qu'el mundo criada» (Vidal González 2003, II: 281) y el «Himno a los gozos de Nuestra Senyora» (ID0073 S 0072) de Pérez de Guzmán («Virgen que fueste criada / ab inicio e eterno; / del rey diuino e superno / elegida e consagrada», Foulché-Delbosc 1912, I: 270, vv. 1-4, cursivas nuestras).

33 En el LV: «Déu infinit, ans que el món fos creat / te preserva puríssima i santa» (n 17, 4ab) y «"Tota est pulcra, amica mea". / [...] responde el mismo profeta / contra argumentos sophismos: / Aun no eran los abismos / "ego jam eram concepta" » (no 32, 4cj). La primera cita, del Cantar de los Cantares (4.7), era muy utilizada en las vísperas de la Inmaculada Concepción (Twomey 2008: 20): acaso Castellví esté refiriendo a este pasaje en su verso "Amiga de Dios...». La segunda cita, es de Proverbios 8, 24 y hace referencia a su creación antes de los infiernos. Del certamen de 1486 véase el poema de Fuster («ans que del món creàs Déu la figura / [...] vós preservà», Ferrando Francés 1983: 438, v. 1b) y el de Miralles («Ans de crear los cels, lum ni planetes [...] / Déu vos creà de parts totes perfetes, / y en vós, sens par, majors virtuts ha fetes», 1983: 514, 1ad).

34 Aquí se reformula otra de las figuraciones de la sabiduría del AT (Eclesiastés 24.9) muy utilizada en la liturgia mariana (Twomey 2008: 191): "Ab inicio et ante secula creata sum, et usque ad futurum seculum non desinam».

35 Aunque puede consultarse al respecto el DME y Kasten and Cody 2001, s.v. sieglo, resulta más interesante la definición s.v. segle del Vocabulari, pues hace referencia al origen bíblico de la expresión: "SEGLE: la vida mundanal, segons I' Escriptura. "No es durable l'alegra d aquest setgle" (Ex proverbiis 
del incunable, de hecho todas las recurrencias de segle acompañadas de artículos definidos se utilizan en este sentido (véanse los poemas $n=2$, verso $1 \mathrm{k}$ y $\mathrm{n}$ 은 27 , versos $1 a, 2 b, 5 a)$. La creación de la Virgen en este mundo entraría, pues, en contradicción con los postulados doctrinales a los que Castellví alude en el resto de su composición. En el caso de la semiestrofa citada, además, sus versos siguen un evidente orden cronológico. Primero se alude a la creación y elección de la Virgen y, luego, a su "nacimiento», por medio de una anáfora («nasciendo nel ventre / nasciendo nel mundo») que no hace más que acentuar la doctrina subyacente: María «nació» en el vientre -y en el mundo-, pues ya había sido concebida / creada, antes del mundo, en el "otro» mundo. En efecto, además de la expresión «otro siglo», ampliamente registrada como referencia al más allá ${ }^{36}-\mathrm{y}$ utilizada frecuentemente en su contrapartida catalana-, ${ }^{37}$

arabum, MS. de Santes Creus, Bib. prov. Tarragona); "Vengren monges de moltes parts per fama e per doctrina d'aquest convidats e per eximplis molt magorment, e molts qui el segle renunciaven" (Vida de sant Apol/loni, ms. Moliné); SEGLE: El món. "Hom qui Rey lo fa cercar, tot lo segle li es poch de fugir" (Bonsenyor, Jafuda Sentències morals, f. 85, col. 1)». Asimismo, los decires narrativos del Marqués de Santillana, que suelen referir constantemente al espacio transmundano o, incluso, escenificar allí la acción, son útiles para ejemplificar cómo el término se usa en relación a uno u otro mundo, dependiendo de la ubicación del enunciador y de la adjetivación asociada. En el sentido de "este mundo»: "porque tan gentil creatura / d'este siglo s'apartava» (Planto de la reina doña Margarida, XVle-g); «[...] su diforme fechura, / digna de ser en el siglo / para sienpre en escriptura» (Infierno de los enamorados, XVac). En el Infierno, el personaje Hipólito utiliza la expresión de modo opuesto, es decir, en referencia al mundo supraterrenal, pues es allí desde donde enuncia («qué fortuna / vos trayo, sin causa alguna, / en este siglo presente», XXXIVh). El personaje Macías, en cambio, refiere al mundo terrenal como "tu siglo»: «plázeme, porque si fueres / al tu siglo trasportado, / digas que fui condenado / por seguir d'Amor sus vías» (LXIVf). En relación a la adjetivación, el espacio paradisíaco es referido por Hipólito como "siglo deleytable» (XXXIIg), mientras que en la Canonización de San Vicente Ferrer aparece como "siglo soberano» (XXh). En el sentido opuesto tenemos "el nuestro siglo mundano» (Infierno..., XXXVIId) y «Dios vos salve, reinas del siglo humanal» (Comedieta, CVIIIc). Citamos por la edición de Pérez Priego (1991), cursivas nuestras.

36 La expresión "otro siglo» se registra en el CORDE en 71 incidencias entre los Ss. XV y XVI.

37 El sintagma altre segle - con su variante formal altre setgle- se registra en 29 ocasiones en el CICA (s. XIV-XVI), en textos como Lo Somni de Metge, Poesies de March, Diálegs de St. Gregori, Libre de Meravelles, etc. En el Vocabulari se registra en 11 ocasiones, en textos de Lull, Eiximenis, etc. Traemos a colación los ejemplos bajo las voces confiantment ("Veiats quant val a I hom just la vida bona e justa, que en aquest segle viu pus segur, e espera confiantment I altre segle», Francesc Eiximenis, Doctrina compendiosa, segona partida, XXI) y martiri («e placia a vos, Senyer, que con mon esser passara d 
en castellano se registra en el mismo sentido la locución «aquel siglo». ${ }^{38}$ Volviendo a la lección original del verso, concluimos que la $c$ del cel no puede ser una errata. En efecto, el catalán medieval escrito recibió gran influencia del provenzal (Moll 2006: 63): algunas de esas marcas son justamente el uso de cell (o aycell) y cest (o aycest) como pronombres demostrativos (véase Lleal 2003:76). El demostrativo cel en «amiga de Dios en cel siglo creada», haría referencia no solo a "aquel siglo», en tanto espacio lejano opuesto a «este siglo», sino que se actualizaría también en un sentido temporal: aquel siglo, es decir, el «primero», anterior a la Creación; al mismo tiempo, dado el primer hemistiquio, "aquel siglo» haría referencia al siglo de Dios.

Resumiendo, el poeta debió elegir la forma provenzal cell - perteneciente a otro sistema lingüístico aunque no del todo ajena- en lugar de aquel, pues le era necesario un monosílabo para respetar la andadura versal óoo óo. En algunas de las composiciones catalanas de $L V$, de hecho, también se utiliza este cell demostrativo en función del metro: «Elet és cell qui és just no h' sospita» (composición no 15, 6b); «si cel vos nomene, estau molt pus alta» [cel, i.e. lo Fill] (no 20, 4f); «Car en lo món fós cel molt gloriós / on er’aquell ab qui lo món salvàs» ( $n$ ㅇ 40, 3d). En estos tres casos puede observarse, asimismo, cómo el pronombre cell en LV oscila ortográficamente en la lateral $(I / / I)$, aun cuando existe el término catalán cel, de sentido diverso (i.e. cielo). Es más, cel -que, como es de esperar, es uno de los términos más recurrentes en $L V$ - también es objeto de oscilación ortográfica: «qui, devallant, ab altres molts del cell» (no 16, 2fg). Explicado nuestro locus tanto desde su contexto semánticodoctrinal como desde su problema grafemático, resta solo aclarar que en nuestra edición conservamos la forma provenzal del demostrativo añadiendo una / para evitar confusiones con el término catalán cel. Este caso, como esperamos haber demostrado,

aquest segle en I autre, que hi pas per via de martiri», Ramon Llull Llibre de Contemplació 21, cap. 94). 38 Véase, por ejemplo, la epístola de la reina María de Aragón, inserta en el Cancionero de Estúñiga ("que asaz título es a mí ser reyna, muger tuya, et morir por tuya. E yr t' é io a esperar en aquel siglo do mi esperança será cierta que non podrás fuyr», Salvador Miguel, 1987: 534) y la «Coronación del Marqués de Santillana» de Mena («Vi a Minos, Redamante / con Eaco aver semblante / de jueces de aquel siglo», 9h, Pérez Priego 1989: 142). 
resulta paradigmático para reflexionar sobre cómo la normalización del diasistema de un texto puede traer consecuencias a nivel del sentido, tan problemáticas como poner en la pluma del poeta una contradicción dogmática.

Volviendo al sistema lingüístico del texto, ambos poemas, como detallaremos en el próximo apartado, presentan múltiples interferencias de índole gráfica, morfemática o léxica del catalán y del aragonés. En algunos casos, dada la ductilidad de los versos - es decir, la posibilidad de ser escandidos diversamente aplicando un metaplasmo u otro (Gómez Redondo 2013: 66) -, es difícil detectar si el catalanismo o aragonesismo fue incorporado a conciencia por el poeta en función del patrón rítmico del verso. Veamos el siguiente caso, de ATF:

$$
\text { Cer|ca|da| de an|gels || e| de| se|ra|fi|nes o óoo óo || o òoo óo (2e) }
$$

Este verso respeta a la perfección la andadura versal del arte mayor, a la vez que presenta una adecuación natural entre el ictus y los acentos gramaticales de los principales términos («cercáda», «àngels» y «serafínes»), aunque requiere una dialefa entre de y àngels. Ferrando Francés (1983: 299) y Sanchis Guarner (1979: 169) enmiendan según el equivalente castellano de àngels, lo cual el patrón rítmico también avalaría aplicando algunos metaplasmos:

$$
\text { Cer }|c a| \text { da } \mid \text { de_án }|g e| \text { les }|| \text { e } \mid \text { de| se|ra|fi|nes } \quad \text { o óoo òo || o òoo óo }
$$

Esta lección, gracias a una sinalefa y a una éctasis (angéles), podría ser admisible según el verse pattern, aunque cabe destacar que la tendencia general del arte mayor es que las sílabas en éctasis se hallen en posición del acento secundario del hemistiquio (Conde 2016: 1030), mientras que aquí coincidirían con el ictus principal. Aclárese también que no sería posible acentuar «ángeles» de manera natural -aplicando dialefa como en el caso anterior - pues, según una de las reglas de compensación del arte mayor enunciada por Lázaro Carreter (1972: 352), si el primer hemistiquio termina en proparoxítona, el segundo debe empezar siempre con sílaba acentuada: en 
este caso el corrimiento de los ictus generaría un segundo hemistiquio proparoxítono — «é de seráfines», lo cual es anormal (Lázaro Carreter 1972: 352, nota 40) y, además, atenta contra el sistema de rimas en -ines-. Podría, en este sentido, postularse que el de del segundo hemistiquio es una adición errónea (por analogía o proyección) del componedor, lo cual sería también posible pues ambas lecciones son gramaticales (de ángeles e de serafines / de ángeles e serafines). Como resulta evidente de este ejemplo, la ductilidad de los versos, debida a la cantidad de metaplasmos que es posible aplicar, dificulta la tarea del editor a la hora de dilucidar cuál podría haber sido la lección del autor y si es pertinente o no enmendar. En nuestra edición, cuando la lección del incunable, a pesar de que pertenezca a otro sistema lingüístico, no atenta contra el patrón rítmico del arte mayor y es explicable ya sea desde una decisión del poeta o desde una interferencia lingüística — del poeta, del componedor o el editor-, la respetamos con el fin de preservar el diasistema lingüístico del texto. Este es el caso de la interferencia morfemática del plural catalán o aragonés (-ns) en este mismo poema:

$$
\text { Tú| de| las | vir|gens || la |per|fec|tión ón óoo || òoo ó[o] (4f) }
$$

Aunque el verso con la lección virgens se ajusta al patrón acentual —como señalamos en 1.1, los ictus del segundo hemistiquio responderían al molde del pentasílabo-, ${ }^{39}$ la opción con el equivalente castellano vírgenes -elegida por ambos editores- sería también adecuada:

$$
\text { Tú| de l las | vír|ge|nes || la | per|fec|tión óoo óøo || òoo ó[o] (4f) }
$$

39 Aclárese que, aún evaluando este verso desde la «ley» de Lázaro Carreter, según la cual en condiciones normales - primer hemistiquio paroxítono- el segundo hemistiquio recibe su primer ictus siempre en segunda sílaba - ley que, como explicamos supra, los estudios de Gómez Redondo permiten cuestionar-, su andadura versal, gracias a dos metaplasmos, también encaja perfecto en el arte mayor: «Tú| de| las| vir|gens || la |per|fec|ti|ón» óoo óo || o òoo ó[o] (4f). 
Más allá de la dificultad de determinar si la interferencia la introdujo el poeta o el cajista, no parece apropiado enmendar un verso que era perfectamente adecuado al arte mayor.

Es menester aclarar, respecto de estos dos últimos casos analizados que, como ya advertiremos, en algunas ocasiones resulta difícil distinguir si una lección se trata de una interferencia o es producto de un error mecánico: angels y virgens bien podrían ser el producto de una omisión del tipo móvil e, como lo ha interpretado Sanchis Guarner -que señala la e entre paréntesis- y seguramente también Ferrando Francés. Sin embargo, dado que ambas lecciones pertenecen al mismo poema y que serían las únicas omisiones de tipo móvil de toda la composición, es curioso que el supuesto error mecánico se dé siempre en el morfema plural. Por tanto, aunque las lecciones podrían ser el resultado de una omisión del componedor, sus características compartidas permiten suponer que dicho error habría sido promovido por una interferencia.

Un problema ecdótico similar se nos presenta no ya a nivel morfemático o léxico sino a nivel sintagmático, en casos donde el componedor pudiera haber alterado o invertido el orden de ciertos términos. En efecto, el caso de la enumeración de epítetos aplicados a la Virgen en DGR es paradigmático:

$$
\begin{aligned}
& \text { Pal|ma| ci|prés| flor || tá|la }|m o| \text { nu|be| lu|na o òoo ó[o] || eo òoo óo } \\
& \text { Tem|plo| go|zo| vi|da || fe| luç| y| lu|ze|ro o òoo óo || o óoo óo } \\
& \text { Ce|dro| nar|do| mi|rra || per|so|na| co|mu|na (3ac) o òoo óo || o óoo óo }
\end{aligned}
$$

Como es regular en esta composición, se observa el primer ictus siempre en segunda sílaba, a costa de una dislocación acentual (éctasis) que resulta un tanto violenta. Los segundos términos de la enumeración, a su vez, quedan átonos. Resulta llamativo, sin embargo, el caso de tálamo que, para adecuarse al patrón - pues, mientras que el hemistiquio anterior termina en oxítona, el final de verso, por la estructura de rima, es siempre paroxítono (Iuna) - realiza una éctasis - desplazamiento de acentode dos sílabas (talamó). Esta extrañeza podría ser fácilmente explicada por un error 
de retención e inversión de términos por parte del componedor, lo cual sería usual al tratarse de una enumeración. ${ }^{40}$ En ese caso, el editor podría preguntarse si sería apropiado enmendar invirtiendo "tálamo» y «nube», a fin de obtener una andadura del verso más natural:

Sin embargo, el desplazamiento acentual violento es muchas veces introducido por el mismo autor para forzar al lector a reparar en algún término. Dado este posible efecto, es preferible no enmendar. Es necesario destacar que la dislocación acentual del primer hemistiquio "palmá cipres flór» también encontraría una solución más natural con la inversión de los dos primeros términos («ciprés palma flór»). En este caso, dado que una de las características de $D G R$ es recibir siempre ictus en segunda, de modo que la dislocación acentual es usual en los primeros términos - la cual se verifica en otros versos que involucran enumeraciones (3b «templó» y 3c «cedró»)-, no habría tampoco argumentos para enmendar. Un caso similar a este es el del verso 5a:

$$
\text { El| sol| e|res| tú || do| fi|zo| Dios| es|tan|cia o óoo ó[o] || øo òoo óo }
$$

Dada la regla según la cual después de un primer hemistiquio oxítono el siguiente puede recibir ictus en segunda o en tercera sílaba, este verso es rítmicamente aceptable gracias a la dislocación acentual en «fizó». ${ }^{41}$ Ahora bien, resulta notorio que, siguiendo

40 Como ya señalamos, el componedor tiende a cometer el mismo tipo de errores que un copista (Pérez Priego 1997: 27-28) al leer y copiar un modelo. Una inversión entre constituyentes coordinados, es decir, situados en un mismo nivel en la estructura gramatical, representa según Fernández Ordóñez (2002: 126) un caso típico de "variación discursiva». En la época de la imprenta, a los errores de transmisión propios de la copia manuscrita, se le suman aquellos mecánicos propios de la nueva tecnología (como tipos volcados, trastocados, etc.). En el caso del error "por alteración del orden», Blecua (1983: 23) señala que el propio mecanismo de composición en la imprenta (la colocación de tipos móviles de manera invertida), lo promueve con mayor frecuencia.

41 No es posible aducir en este caso un acento en segunda («do fizo Dios estancia») pues el acento de 
el orden sintagmático más común en castellano (sujeto+verbo), obtendríamos un verso más natural:

$$
\text { El| sol| e|res| tú || do| Dios | fi|zo_es|tan|cia o óoo ó[o] || o óoo óo }
$$

Aunque esta dislocación podría ser un metaplasmo introducido por el autor, podría también tratarse de un error de retención e inversión entre los términos fizo y estancia por parte del componedor, el cual hubiera generado como efecto un verso igualmente aceptable, con un metaplasmo. Se trata de un metaplasmo común éctasis: desplazamiento del ictus solo a una sílaba- y, por tanto, no habría argumento para enmendar un verso de por sí correcto.

Culminaremos el apartado con algunos casos en los que la inadecuación del verso al patrón rítmico no deja lugar a dudas sobre la necesidad de enmienda. Mencionemos, en primer lugar, un caso de hipermetría en la composición DGR:

Pues $\mid$ to $\mid$ dos $\mid$ tus $|a c|$ tos || por| siem|pr'an| me|re|ci|do oóoo óo || oo óoo óo (2f)

El problema se da, en este caso, en la zona de cesura pues, en condiciones normales - un primer hemistiquio paroxítono-, el acento del segundo hemistiquio cae en segunda sílaba (Conde 2002: 262; Lázaro Carreter 1972: 352) y en otras ocasiones en primera: nunca en tercera. No sería posible postular un ictus natural en «por siémpre», pues el patrón óoo ó exigiría un adelantamiento del ictus de «merecido», inaceptable dado el esquema de rima (merecido/subido/vencido). La anomalía, por tanto, deja en evidencia un error por parte del componedor - el agregado de la preposición «por», seguramente por atracción de la frecuente expresión "por siempre»-que exige enmienda: "Pues todos tus actos siempre'an merecido». Como se deduce de estos casos, el esquema de rimas juega también un rol importantísimo a la hora de determinar metaplasmos y posibles enmiendas.

«estancia» es inamovible, dado que determina la estructura de la rima (estancia/constancia). 
Un caso similar de hipermetría se observa en el verso if de ATF ( «Yo) con|quis|tan|do || con| mi| va|no| pla|zer»: óoo óo ||oo óoo ó[o]), en el que el ictus del segundo hemistiquio también cae en tercera, con un primer hemistiquio paroxítono. Tampoco es posible postular una dislocación acentual, pues el esquema de rima exige un ictus oxítono en «plazer». Además, si leemos el verso en su contexto - «yo conquistando con mi vano placer / dormiendo ' $\mathrm{n}$ un letxo con bellos cotxones / fui transportado en un lindo vergel / muy oloroso de grande valer / segund que verés en mis conclusiones» (1fj) - vemos cómo el verboide conquistando no parecería tener objeto. Deducimos, por tanto, que el con fue una adición - proyección discursiva, en términos de Fernández Ordóñez (2002: 119) - del componedor, que exige enmienda tanto por la andadura rítmica del verso como por su sentido: "Yo conquistando mi vano plazer» (óoo óo || o óoo ó[o]).

El sistema de rimas en el que entra este verso (placer/vergel/valer) merece unas palabras pues, al representar vergel un caso de "consonancia imperfecta», podría postularse la poca maestría del poeta. El poema de Pere de Civillar, de hecho, ha sido valorado negativamente - «la composició resulta poc imaginativa i ben pobra en recursos estétics» (Ferrando Francés 1983: 238) - y se ha incluso sugerido que se trata de un plagio de "Al tiempo que Apolo en fuerza crecía» de Pedro de Guillén de Segovia [ID1740]. Sobre esta rima problemática, Clark (1949: 1114-1115) ofrece numerosos ejemplos que prueban cómo la equivalencia acústica entre ciertas consonantes, de las cuales la más común es justamente la $r$-l, era utilizada por poetas de cancionero: Juan de Mena, Gómez Manrique, Diego de Valencia, Fernán Pérez de Guzmán, entre otros. En el caso de esta semiestrofa, además, vergel es el término clave: por un lado, es el escenario donde el yo-poeta tendrá su visión de la Virgen; por el otro, si relacionamos su descripción — «de grande valer / segund que verés en mis conclusiones»- con los versos conclusivos del poema, todos referidos al "valer» de la Virgen, resulta evidente que se propone una identificación entre Virgen y vergel. ${ }^{42}$

42 Más allá de la amplia tradición de la imagen del prado asociado a la Virgen, la identificación 
Siendo el vergel el mismo espacio de la escena, resulta un juego poético relativamente singular, que entronca con la tradición del prólogo berceano. Finalicemos este apartado señalando que la valoración del poema como "plagio» tampoco tiene fundamento: por un lado, la relación entre el poema de Civillar y el de Guillén se reduce, más allá de ser ambos decires en arte mayor, a la referencia temporal con la que abren: "Al tiempo que Apolo» / «Al tempo que Febo». En efecto, la visión de Guillén transcurre en el Monte Parnaso, donde ve a Apolo, a las Musas, a poetas y sabidores, y culmina en un diálogo - formato de pregunta y respuesta - con la Filosofía. ATF, en cambio, parece entroncarse más directamente a la tradición de las visiones de Santillana: tenemos el inicio con una referencia temporal alegórica, el motivo del lecho y el rapto, el vergel o foresta como espacio supra-terrenal, el contenido alegórico de la visión, ${ }^{43}$ que presenta en realidad resonancias bíblicas. Por otro, la utilización de estos motivos, frecuentes en la tradición cancioneril a partir del impulso de Santillana y la escuela alegórico-dantesca, no implica de por sí un plagio; al contrario, tomar los motivos que ofrece la tradición y variarlos constituye la práctica más usual en la poesía. La opción por el formato del decir, además, le da a esta loa de la Virgen un marco narrativo - que permite a la vez insertar un yo-, procedimiento original respecto de los otros poemas / loores de LV. La maestría poética de Castellví es, sin dudas, incuestionable: sirva este breve excursus para revalorizar al desconocido Civillar.

específica vergel / Virgen se halla en la tradición cancioneril: véase "A santa Leocadia» [ID0082] de Fernán Pérez de Guzmán («la mi gloria es el vergel / do Su carne fue ençerrada», GB1 96r), poema de gran difusión como demuestran los 12 cancioneros en los que se transmite (Philobiblon BETA 4653). EI vergel como espacio visionario y a la vez alegórico es estudiado por Ferrari 1974. Nótese que tanto en Razón de Amor, como en los loci amoeni de la poesía cancioneril, suele representar un espacio edénico amoroso. En ATF el vergel en tanto espacio edénico visionario no solo se identifica alegóricamente con la Virgen, a la manera berceana, sino que la Virgen es el personaje de la visión. Para la identificación vergel-mujer desde la tradición bíblica, véase Ross 2008.

43 Véanse especialmente: Visión, Defunssión de don Enrique, Canonización de Vicente Ferrer, el Infierno de los enamorados, El Sueño. 


\section{INTERFERENCIAS LINGÜÍSTICAS: ANÁLISIS Y PROBLEMAS}

Entre el catalán y el aragonés: ¿interferencias del poeta, del componedor o del editor?

Hemos ya destacado el complejo diasistema del que emergen los poemas castellanos de $L V$, así como los problemas ecdóticos que pueden generarse si no se respetan sus interferencias lingüísticas (casos de cel, àngels, etc.). En efecto, el sistema lingüístico del texto (castellano) difiere del sistema del poeta (esto, al menos, puede plantearse con seguridad en el caso de Castellví, valenciano), del sistema del editor (Fenollar) y, a la vez, del sistema del componedor, probablemente también perteneciente a la comunidad lingüística valenciana; los cajistas, como ya señalamos se comportan como un copista, siguiendo sus propios hábitos lingüísticos. ${ }^{44}$

Resulta pertinente realizar un breve excursus sobre la situación lingüística propia del Reino de Valencia, que resultaba ser una zona de contacto y superposición de lenguas. ${ }^{45}$ Desde el siglo XIII y las tempranas migraciones de población catalana, aragonesa y, en proporción bastante menor, castellana, se registran casos de influencia entre el aragonés y el catalán. Así, en el siglo XV contamos con un proceso de contacto de casi dos centurias. ${ }^{46}$ En efecto, Ferrando Francés (1989: 406) señala que «qualsevol intent d'explicació dels origens del valencià no pot prescindir de l'element aragonés»,

44 Para el estudio de un caso concreto de interferencias lingüísticas introducidas durante la etapa de impresión, véase el caso de los aragonesismos en Grimalte y Gradisa, tema abordado recientemente por Parrilla (2017).

$45 \mathrm{El}$ enclave del Reino de Valencia hace plausible al contacto lingüístico pues tiene frontera con Castilla y Aragón. Esto genera, según Fort i Canellas (2002: 111), un fenómeno de continuum entre diversas lenguas.

46 Para un desarrollo más profundo del complejo proceso histórico y demográfico de "repoblaciò» del reino de Valencia, así como de sus consecuencias lingüísticas, véase Ferrando Francés 1989, quien basado en un análisis de los Llibres del Repartiment de Valencia presenta numerosas críticas a la teoría de la «reconquista» abanderada por Badia 1981. Para el caso específico de las migraciones de población catalana, aragonesa y castellana en la zona véase también Frago Gracia (2009: 52) y Martines (2002: 157). El temprano contacto entre lenguas se nota también en el carácter políglota de textos de cancillería de la Corona de Aragón del siglo XIII, como el Ceremonial del rey Pere IV (Valencia, 1353) redactado en latín, catalán y aragonés (Fort i Cañella 2002: 112-113). Sobre el uso del catalán en la Cancillería de la Corona de Aragón, véase González Ollé 2009: 85 y Lleal 2003: 82. 
el cual influyó sobre todo en la lengua coloquial. ${ }^{47} \mathrm{~A}$ su vez, el castellano que hablaban en Valencia los inmigrantes castellanos o sus descendientes tenía obviamente como lenguas de adstrato el catalán y el aragonés. Finalmente, el sistema lingüístico valenciano sufrirá cambios durante los siglos XIV y XV, derivados de factores políticos, ${ }^{48}$ que terminarán por cristalizar en la revalorización del castellano-aragonés (Casanova 2011: 220). La actitud de los Trastámara de Aragón, quienes continuaron usando el castellano en su corte, aunque con rasgos muy aragoneses, debió haber influido en este cambio. ${ }^{49}$ Así, de forma paulatina se observará en la corte de Valencia una marcada preferencia por el castellano, la cual influirá también en la práctica literaria. ${ }^{50}$ Dado que todo cambio de lengua deja marcas (Casanova 2011: 204), ese castellano adoptado en la corte tenía no solo vestigios del aragonés, sino que paulatinamente recibiría influencia del valenciano o catalán de sus hablantes.

Repasado someramente este complejo panorama lingüístico, intentaremos aquí realizar una tipología de las interferencias más importantes que hemos detectado

47 Las causas que explican la formación y características particulares del catalán occidental, así como específicamente de la variedad valenciana, han sido fruto de un intenso debate entre lingüistas, para el cual remitimos, además de al ya mencionado estudio de Ferrando Francés (1989), al más reciente Veny (2015), donde se repasan de manera muy clara las diversas teorías.

48 González Ollé (2009: 91) puntualiza que la crisis política, social y económica suscitada en Cataluña durante el siglo xIV provocó cambios lingüísticos en la Corona de Aragón que decantarían en la preferencia del uso del castellano en la región, desplazándose al catalán. Tal como señala Pérez Bosch (2009: 17), el poderío valenciano durante los siglos XIV y XV explica su diferenciación lingüística.

49 Ferrando Francés (1982: 105-106) señala la importancia de la dinastía Trastámara en la Corona de Aragón como el punto de quiebre para la imposición del castellano en la región. González Ollé (2009: 94), en efecto, prueba a través de diversas cartas que Fernando I utilizaba el castellano en el ámbito familiar. Lleal (2003: 82), asimismo, advierte que, si bien el castellano fuera elegido como lengua para los textos de cancillería, ciertas particularidades del aragonesismo resistían y podían notarse en los textos de escribas de la corte aragonesa. Sobre la preferencia del castellano frente al aragonés como marca de distinción social a fines del siglo XV, véase Mateo Palacios 2014: 93, Sanchis Guarner 1979: 13-14 y Ferrando Francés 1982: 113-114.

50 En algunos casos, como señala Ferrando Francés (1982: 114) se trata de una actitud de «mera exhibició de poliglotisme». Respecto del abandono del catalán por el castellano en la poesía como rasgo aristocratizante véase Lleal 2003: 86, Pérez Bosch 2005: 356 y Mateo Palacios 2005: 90. Sobre el bilingüismo de poetas valencianos, además de Ferrando Francés, véase Pérez Bosch 2009: 45 y 55-56. 
en $D G R$ y ATF - las cuales serán señaladas en su totalidad en la edición crítica- que, como ya señalamos, podrían haberse incorporado tanto en la etapa compositiva - por parte del poeta-, como durante el proceso de impresión - por parte del componedor o del editor- En nuestro estudio hemos seguido de cerca los trabajos de Alvar (1987 y 1958-1959), Giralt Latorre (2018), Gómez Fragas (1989), Arnal Purroy \& Enguita Utrilla (1993), Mateo Palacios (2014) y Enguita Utrilla (2009). Asimismo, a la hora de sopesar cada interferencia, hemos recurrido a corpus informatizados como CORDE, DiCCAXV, CICA y el Vocabulari de la Llengua Catalana Medieval de Lluís Faraudo de SaintGermain (Vocabulari). Para la fundamentación específica que nos permitió valorar las interferencias, así como para el reenvío a la bibliografía pertinente, remitimos a las notas de la edición crítica. En efecto, dado que el contexto en el que cada término funciona, así como las interferencias que lo rodean, fueron fundamentales para sopesar su naturaleza, preferimos reservar las notas lingüísticas para vincularlas al texto crítico.

Las posibles interferencias lexicales detectadas pueden dividirse en dos tipos:

a. interferencias "puras»: en DGR ventre (2c); cent (3d), dotze (4b),,$^{51}$ estella (4b); ${ }^{52}$ en ATF àngels (2e), dolçor (3f), vit (4c), perles (5b), visrey (6a), sempre (6e). Se tratan de catalanismos lexicales.

b. casos en los que un lexema catalán podría haber interferido en una realización intermedia entre el castellano y el catalán: en DGR teniebras (4e, interferencia de tenebres), vergen (5c, interferencia de verge); en ATF

51 Aunque dotze parece una evidente interferencia léxica (véase s.v. Vocabulari), es preciso destacar que entre los casos de regularizaciones sistemáticas de grafías posiblemente imputables a mosén Fenollar, Ferrando Francés (1999: 122) señala el caso de la -tz en sol/lempnitzada, preconitzant, sinderitzant, organitzada, organitza. Dado que no hay otro caso de grafía con -tz en las otras tres composiciones en castellano, resulta difícil definir si este también es un caso de regularización gráfica. Lo cierto es que una interferencia en el numeral por parte del autor, en tanto término de uso muy frecuente, puede ser igual de plausible. En la misma composición, en efecto, tenemos el caso de cent. De cualquier modo, nos detendremos en breve en el problema de los términos para los cuales resulta difícil distinguir si la interferencia que opera es léxica o gráfica.

52 Nótese que estella se registra en el Vocabulari como variante formal del catalán estela. 
tempo (1a, interferencia de temps); teniebra (1c, interferencia de tenebra), antigüidat (1d, interferencia de antiguitat), certo (1e, interferencia de cert), gesmines ( $2 b$, interferencia de gessami).

Hemos detectado, asimismo, catalanismos y aragonesismos morfemáticos: lo (artículo nominativo catalán o aragonés: $D G R$ 1i), otri (indefinido aragonés: $D G R$ 4j), per (preposición catalana: DGR 5d), li (dativo catalán o aragonés: ATF 2j), virgens (plural catalán -ns: ATF 4f), fue (pretérito aragonés en primera persona de ir: ATF, $1 \mathrm{~h})$. En algunas ocasiones resulta difícil definir si se trata de un catalanismo léxico o morfemático; es el caso de àngels y perles: ambos a primera vista se clasificarían como interferencias lexicales pero, dado que el lexema singular es igual en castellano y en catalán (angel/perla), la interferencia podría derivar de la formación del plural: en un caso $-s$ y en otro -es.

El tipo de interferencia más importante es, sin embargo, aquella que se da a nivel grafemático: un término castellano se ajusta a una realización gráfica propia del catalán o del aragonés. ${ }^{53}$ Los casos son numerosísimos y se encuentran detallados en la edición crítica; mencionemos aquí los más repetidos y/o significativos:

- $\quad$ - expletiva o inorgánica al inicio y al interior del término: hi (DGR 1a, 3e, 4e, ATF, 1c), lohor (DGR 1g), ahun (DGR 6e, ATF 5d), lohando (DGR 2f), cahí (ATF 2g), loha (ATF 3d), lohada (ATF 5g, 6e).

- - u superflua tras velar /k/ o /g/, rasgo predominantemente aragonés, aunque también se observa en catalán: nunqua (DGR $1 \mathrm{~h})$, patriarqua (DGR $1 \mathrm{~h}, 2 \mathrm{j})$, riquas (ATF $5 \mathrm{~b})$, huelgua (DGR $1 \mathrm{~d})$.

53 Ferrando Francés (1983: 300), para el caso de ATF, señala: «són nombrosos els noms que, com cotxones, apareixen escrits en grafia catalana (mutxo, ditxos, sachó, sallió, perles, riquas, aquell, etc.)». Más allá de que destaque solo algunas de las tantas interferencias grafemáticas -y solo para este poema, es decir, no para los restantes tres castellanos-, cabe puntualizar que en perles (véase nota de edición crítica $5 b$ ) se observa más bien una interferencia lexical (del catalán perla/perles) o, si se quiere, morfemática (del plural femenino en -es). El caso de riquas es también problemático, sobre todo teniendo en cuenta que Ferrnado Francés edita riques, transformando el riquas en un catalanismo lexical. 
- $-t x$ con valor -ch /ĉ/, rasgo típicamente catalán: dretxa (DGR 3h), etxar (DGR 4e), mutxo (DGR 4f), letxo (ATF 1g), cotxones (ATF 1g), ${ }^{54}$ ditxos (ATF $3 c)$.

- $\quad$-ch y -cc con valor / $/$ /, rasgo catalán y aragonés, aunque en ciertos casos podría también tratarse de un cultismo: nuncha (DGR $2 \mathrm{c}$ ), patriarcha (DGR 6a), sachó (ATF 4g), peccadores (DGR 1b), peccado (ATF 3e).

- Uso de II con valor I y de I con valor de II: rasgo catalán y aragonés (oscilación presente también en los poemas catalanes de $L V$ ): sallías (DGR 4d), aquell (ATF 4d), sallió (ATF 4i), legar (DGR 1i), cel (DGR 2a).

- -ni/ny para representar el valor palatal $/ \mathrm{n} /$, rasgo catalán y aragonés: danio (DGR 5e), prenyada (DGR 5g), senyora (ATF 4c, 5c), senyor (ATF 6a), senyoría (ATF 6b).

- $\quad-t$ con valor ç /ŝ/, rasgo predominantemente aragonés, aunque podría también tratarse de un cultismo: en ATF devotión (3d), scientia (3h), proffetía (3h), salvatión (3j, 5f), coronatión (4h), perfectión (4f, 5h), discretión (5i).

- Trueque de grafías en palatales, ante vocal central o velar, rasgo típicamente aragonés: $g$ en lugar de $j$ e $i$ que usualmente representan el fonema /ž/. Alvar (1987: 22) ofrece ejemplos como Botaga (i.e. Botaya), sago (i.e sajo) mientras que Gómeza Fragas señala enogar, gamás, gardin, viego (1989: 31). En el caso de DGR tenemos figo (por fijo): dado que la interferencia genera confusión con un término coexistente (figo de ficus)

54 Nótese aquí que, además de la interferencia grafemática, pareciera omitirse el tipo $l$, requerido en colchones. Sin embargo, el castellanismo cotxa que se registra hoy día en catalán (véase Diccionari catalá-valenciá-balear s.v. cotxa), pareciera indicar que la pérdida de la / ante -ch seguramente se deba a un proceso fonético propio del catalán, que interfirió en ambos términos de manera similar, aun con distancia de varios siglos. 
resultó necesario enmendar. Es pertinente destacar que esta característica se da también en los dos poemas castellanos no analizados aquí: en el noㅡ 32 tenemos en rima aparega ( $3 a$ ) y vega ( $3 d$, i.e. vieja). Acaso el trueque involucre algún componente fonético: en la composición no 7 se ubican en rima fija (fiia) y fatiga, lo cual permitiría hipotetizar que esa $g$ tal vez se pronunciara como una palatal sonora. ${ }^{55}$

- $-t$ por sonido dental sonoro /d/, este rasgo, más fonético que grafemático, es típicamente catalán y aragonés: Davit (DGR 3i), antigüidat (ATF 1c), claridat (ATF 1a), vit (ATF 4c).

En la mayoría de las ocasiones, como han señalado Martines (2002: 159), Casanova (2011 207-8) y resulta evidente de esta clasificación, la similitud estructural y evolutiva entre el catalán occidental y el aragonés vuelve difícil distinguir si un rasgo presente en los poemas castellanos pertenece a un dominio lingüístico o al otro. Esta no es, sin embargo, la única dificultad. Algunos de los casos que clasificamos como interferencia grafemática, por ejemplo, podrían de igual modo ser considerados lexicales: por un lado, nuncha (DGR 2c), prenyada (DGR 5g), patriarchas (DGR 6a), vit (ATF 4c), senyora (ATF 4c y 5c), senyor (ATF 6a), senyoria (ATF 6b) podrían explicarse desde sus exactos equivalentes catalanes; por el otro, peccadores (DGR $1 \mathrm{~b}$ ) y peccado (ATF 3e) podrían resultar de la interferencia de peccadors y peccat; así como danio (DGR 5e) de la interferencia del catalán dany. Asimismo, teniendo en cuenta la probable instancia de regularización gráfica que habría llevado a cabo Fenollar, algunos de estos rasgos, especialmente aquellos que en ambas composiciones representan de manera sistemática y exclusiva el mismo fonema (como las grafías -tx y -ny), podrían acaso ser fruto de su participación. Al respecto resulta pertinente sopesar el caso de -cc en

55 Así como Frago Gracia (1991: 125-126) destaca respecto de Marcuello que rime maravillo con fillo (fijo) y bello con consello, aprovechando variantes fonéticas coexistentes promovidas por el bilingüismo, aquí habría que considerar también la posibilidad de que la interferencia fuera introducida por el poeta en función de la rima. 
peccadores y peccado a la luz del hecho de que todas las ocurrencias de estas voces en los poemas catalanes de $L V$ (peccador/s; peccat/s) presentan doble -cc. En efecto, en el caso de los poemas castellanos podría acaso postularse que esta grafía fuera un cultismo. Sin embargo, al menos para el caso de Castellví cuyo origen no es objeto de dudas, resulta muy difícil aseverar si se trata de un latinismo o de una interferencia catalana dado que, al ser esa la grafía que el término adopta en su lengua materna, es muy plausible que interfiriera en su escritura. Acaso pueda también adjudicarse la grafía de ambos casos a una regularización orientada al catalán por parte de Fenollar, aunque en este caso habría que señalar que en el poema castellano no 7 se registra pecadora (1a), con una sola $c$.

Asimismo, algunas de las posibles interferencias puras, como ventre o sempre (DGR 6e), o de las interferencias que derivan en realizaciones intermedias, como certo (ATF 1e) o tempo (ATF 1a), podrían acaso haber sido fruto de una regularización de Fenollar, de acuerdo a la ausencia de diptongación de la vocal tónica latina ĕ en el catalán. Sin embargo, este rasgo -i.e. la reducción diptongo castellano ie en e- no resulta sistemático: además de que su realización varía en la misma composición -tenemos sempre (DGR, 6e) / siempre (DGR 2f) y certo (ATF 1e) / cierto (ATF, 3g;)hay casos de términos con diptongo que no se reducen (teniebra, DGR 4e y ATF 1c; cierto, $\mathrm{n}$ - 32, 2e). La interferencia, por tanto, no puede ser adjudicada con seguridad al editor: bien podría haber sido incorporada por el autor o el cajista.

En relación a la praxis ecdótica, es de destacar que en algunas ocasiones resulta difícil determinar si una lección responde a una interferencia o a un error mecánico producido durante el proceso de impresión: así, los casos ya vistos de estella y virgens podrían deberse a una omisión de tipo móvil ( $r$ y e). Para el caso de espijada, a su vez, sería posible postular un error en la elección del tipo: $i$ por e. Intentar distinguir una interferencia de un error mecánico es crucial, sin embargo, pues cada opción lleva a decisiones editoriales contrarias: respetar la lección o enmendar. Son las características lingüísticas del propio poema, así como del resto del testimonio, las 
que inclinan a favor de una opción: así, aunque legar podría deberse a una omisión de tipo, la oscilación de la grafía en las líquidas es característica de todo $L V$. En el poema castellano no 7, por ejemplo, se lee «lorando» (5c).

El caso de espiiada, de hecho, es ecdóticamente problemático pues puede interpretarse desde dos interferencias diversas. La lección podría deberse a la interferencia del catalán espill, el cual es utilizado por el mismo Castellví en la composición inmediatamente anterior: «Mare de Fill al qual sóu vera fillia / empelt novell florint fuita novella, / dau-nos espill de la llum que us espilla. / Per un dir bell de vós, flor sempre bella» ( $n$ 4, 1ad). Como en nuestro poema, el término está rodeado de una serie de epítetos marianos pertenecientes al campo semántico vegetal: empelt/florint fruita/flor. Destaquemos que, aunque el extendidísimo epíteto mariano es estrictamente Speculum Dei, Ecclesiae, Sanctitatis, Iustitiae etc., ${ }^{56}$ se registra también el participio «speculata» en el Opus sermonum de Adventu (1516) de Jean Raulin, autor monástico que vive entre los ss. XV y XVI: «Maria quae speculata est humanitatem unitam deitati» (f. cviii [04r]). ${ }^{57}$ En el verso «del muy Soberano espijada rosa» (i.e. espejada, como enmienda Sanchis Guarner) se amalgamarían, por tanto, dos epítetos marianos de amplia tradición - rosa y speculum -: «rosa que es espejo [de la luz] del Soberano». Podría también argumentarse, teniendo en cuenta el ya mencionado común trueque aragonés de las grafías $y / i$ del fonema prepalatal fricativo sonoro /ž/ con la $g$ del fricativo velar sonoro /g/, que espiiada se trate de un caso de interferencia grafemática aragonesa, es decir de $i$ con valor de /g/. En efecto, el término espigada, en tanto perteneciente al campo semántico de lo vegetal, podría también aplicarse a rosa. «Rosa espigada» se referiría, acaso, a una rosa fecunda o que fructifica (véase el DME, s.v. espigada). Así es, de hecho, como Twomey (2008:

56 Para las diversas advocaciones marianas en relación a speculum, véase Disalvo 2013:402 y Migne 1844-1855.

57 Citamos por el ejemplar que se encuentra en la Bayerische Staatsbibliothek, bajo la signatura 4 P. lat. 1079. 
159) interpreta esta lección al traducir y comentar el pasaje. ${ }^{58}$ Recordemos que la espiga, además, es donde se contiene el grano con el que se hará luego el pan y que Cristo es justamente el "Pan de vida» (Juan 6, 35)..$^{59}$ Siendo que habría elementos para sostener que la lección original habría sido ya sea espejada, como edita Sanchis Guarner, ya sea espigada, como traduce Twomey, conservamos, como Ferrando Francés, la lección espijada pues, además de que ambas hipotéticas lecciones serían fruto de una interferencia propia del diasistema del texto, esta opción editorial no cierra la posibilidad de interpretar el verso de acuerdo a dos maneras tan productivas.

Como probablemente ya quedó claro, intentar definir el origen de las interferencias, esto es, si fueron introducidas por el poeta, el editor o el cajista, resulta dificultoso la mayoría de las ocasiones. Hemos comentado algunas que de manera más o menos probable pueden adjudicarse al editor. Resulta interesante tener en cuenta también el caso de las diversas realizaciones del nexo coordinante, del que tenemos en DGR las siguientes incidencias: $y / i$ se registra en 7 ocasiones, e en 1, hi en 3 . En ATF, en cambio, la incidencia del nexo castellano y asciende a 9, mientras que $h i$ se registra solo una vez. No parece casual, por tanto, que la interferencia hi sea más incidente en el poema de autor valenciano que en el poema de autor supuestamente castellano. En efecto, el origen posiblemente castellano del poeta de ATF acaso permitiría avanzar la hipótesis de que el único hi que se registra fuera una interferencia del cajista. Para $D G R$, en cambio, no es posible definir si las interferencias en el nexo las produjo el valenciano Castellví, el cajista o alguna cada uno. Sí resulta poco probable que fueran fruto de Fenollar, pues las diversas y numerosas variantes demuestran una falta de regularización gráfica.

58 Twomey traduce de la edición de Ferrando Francés así: «Of the most High Sovereign, rose in full bloom / on whom the Eternal One takes his ease and rests» (2008: 159). Como se acentúa en el comentario posterior ("Mary is the full-blown rose, which provides a resting-place on its petals») su lectura deriva de espigada y no de espejada.

59 En el siglo XV el término espigado se registra en el CORDE en cuatro ocasiones: dos en relación adjetiva con nardo (1490, Universal Vocabulario y c. 1485, Evangelios y epístolas de García de Santa María), una con manojo [de trigo] (1494, Carta de Colón a los reyes) y otra con pan (Biblia ladinada, c. 1400). 
El caso de la interferencia grafemática catalana - $t x$ para el fonema /ĉ/ es quizá la más significativa: si Civillar era castellano e, incluso, si fuera aragonés como sugeriremos en el próximo apartado, difícilmente podría provenir de su pluma esta interferencia, más teniendo en cuenta que es extensiva a todas las representaciones del fonema. ${ }^{60}$ La interferencia acaso sea del cajista o del editor, tanto aquí en ATF como en $D G R$, donde las 3 incidencias del fonema también presentan la misma realización -tx. Sin embargo, dado el origen valenciano de Castellví, no es posible afirmarlo con total seguridad para DGR. Sí es posible avanzar la hipótesis de que, ya que -ch suele utilizarse como representación del fonema velar / $k /$ tanto en estos poemas como en valenciano en general, el editor Fenollar podría haber deliberadamente optado por esa representación - $t x$ del fonema /ĉ/.

Siguiendo el criterio del origen del poeta Civillar, también podría concluirse que los posibles catalanismos léxicos de ATF, sean puros o intermedios, fueron introducidos durante la etapa de impresión: tempo, gesmines, dolçor, perles.

Otro caso interesante de ATF es el del término en rima vit (4c), pues los otros términos del sistema, esto es, sentid (4a) y David (4d), reciben una realización gráfica de dental típicamente castellana. En $D G R$, de hecho, también se menciona a este personaje, pero recibe la representación en oclusiva sorda Davit (3i), lo cual allí podría ser una interferencia grafemática aragonesa o catalana del poeta o del componedor - la falta de regularidad gráfica acaso permita descartar a Fenollar-. En el caso de $A T F$, en cambio, parece más probable que la interferencia fuera del cajista: además de que la realización sorda de la oclusiva dental final ya era rara en castellano (Menéndez Pidal 1952: 255) - vit se registra en el CORDE, entre el 1400 y 1550 solo dos veces, en un texto leonés-, y del probable origen castellano del poeta, una realización diversa de términos en rima no tendría justificación ni fonética ni, sobre todo, gráfica, si fuera del poeta. Aunque se postule, como sugeriremos luego, un posible origen aragonés

60 Téngase en cuenta, por ejemplo, el caso de la /k/ en nunqua (1h) / nuncha (2e) y patriarqua (2j) / patriarcha (6a), pues recibe realizaciones diversas en la misma composición (DGR). 
del autor $y$, por tanto, cupiera la posibilidad de que esta $-t$ fuera una interferencia fonético-grafemática del poeta, hay que tener en cuenta que la rima tiende a ser un fenómeno tanto fonético como gráfico, es decir: el poeta tendería a rimar todo el sistema bajo la misma realización gráfico-fonética: sentit/Davit/vit o bien sentid/David/ vid. Tenemos en $D G R$, por ejemplo, la rima estellas/vençellas, en la que el poeta elige una realización palatal del infinitivo+enclítico - que conlleva una correspondiente realización gráfica - , para rimar con estellas. ${ }^{61}$

Al comienzo del poema ATF, sin embargo, sí tenemos una realización oclusiva sorda final en términos en rima: claridat/escuredat/antiguidat. En este caso, dado que la interferencia - $t$ resulta consistente en los tres términos, parece menos probable, aunque no imposible, que provenga del cajista. Para complicar el panorama, se registra claridat (2j) y claridad (4g) en interior de verso. Aunque el caso de claridad avalaría la hipótesis de que la - $t$ de las otras lecciones fueran interferencias del cajista, la oscilación podría deberse al propio poeta. En efecto, claridat se registra en el CORDE (s. XV) en 244 ocasiones en textos castellanos y, primordialmente, aragoneses (frente a 512 de claridad). En el DICCA-XV la variante con -t se registra en 22 casos, frente a 15 de claridad. La realización en - $t$ final de los otros términos también se halla en el CORDE: escuridat (55), oscuridat (11); antiguedat (18). ${ }^{62}$ En el DICCA-XV (s.v. oscuridad) la variante con - $t$ (escuridat/scuredat) se da en 8 casos, mientras que antiguidat/antiguedat en 5 . Acaso fuera la frecuencia del término claridat lo que determinara la elección del sistema de rimas en términos que, a diferencia de vit, están registrados en castellano. ${ }^{63} \mathrm{~A}$ la luz de otros muchos aragonesismos de este poema,

61 Según Lázaro Mora (1978: 272), la asimilación -rl en palatal era más frecuente en textos literarios medievales de lo que señala Menéndez Pidal (1952: 255). El crítico ofrece numerosos ejemplos de poetas del siglo xV que las utilizan (Mena, Encina, Gómez Manrique, Fray Íñigo de Mendoza), aunque algunos las prefieren convenientemente solo en posición final, para efectuar rimas heterocategoriales, como la que se observa aquí.

62 La incidencia en el CORDE de las variantes de estos términos en - $d$ final es mucho mayor: escuridad (139), oscuridad (44), antiguedad (129).

63 La elección de la - $d$ final en el sistema de rimas vit/sentid/David, puede haber estado influida por la 
podría inferirse que este sistema de rimas fuera fruto de una interferencia aragonesa del poeta. ${ }^{64}$ Destaquemos, asimismo, que las lecciones escuredat y antiguidat parecen presentar también interferencia catalana, como evidencia el cambio de timbre en ambas vocales pretónicas. Escuredat, de hecho, es un término catalán (véase s.v. Vocabulari), mientras que antiguidat parece estar influido por antiguitat. Aunque lo complejo del panorama dificulta la valoración lingüística de las lecciones, acaso no sea del todo aventurado proponer aquí una interferencia doble: una durante el proceso de composición y otra en el de impresión. Así, escuridat y antiguedat, registrados en castellano y en aragonés, podrían haber sido las lecciones primigenias del poeta, que podrían haber derivado durante la impresión en escuredat y antiguidat. En efecto, es más probable que se produzca una interferencia del cajista en el proceso de lectura y retención cuando el término a copiar se asemeja más al de su propio idiolecto.

Otras interferencias, que inciden en la andadura versal del poema, sí pueden fácilmente reconocerse como fruto del poeta. Ya mencionamos los casos de cel (DGR

desinencia verbal de la segunda persona plural — sentid-, pues ya era rara en castellano la terminación en $-t$.

64 Es preciso aclarar que, aunque en textos castellanos suelen, de manera oscilante, registrarse términos en -dat, su incidencia es muy baja. Téngase en cuenta el caso de Alfonso de Palencia, que registra en el CORDE 2085 usos de términos en -dad (1881 en el Universal Vocabulario y 204 en el Tratado de perfección, véase CORDE «*dat»), frente a solo 3 en -dat (todos concentrados en el Tratado -el resto de las incidencias corresponden a la columna latina del Universal Vocabulario-). Algo similar se observa, por ejemplo, en el castellano Diego de Valera; el total de 863 registros de voces en -dad y 139 en -dat se reparten en su obra de la siguiente manera: Crónica de los Reyes Católicos (-dad 698, -dat 0), Tratado de las epístolas (-dad 114, -dat 0), Cirimonial de príncipes (-dad 34, -dat 0), Tratado en defensa de virtuossas mujeres (-dad 15, -dat 85), Tratado de las armas (-dad 1, -dat 50), sus poemas en el Cancionero de Estuñiga (-dad 1, -dat 4). De estos números resulta evidente la preferencia por la terminación en - $d$ de manera exclusiva en los primeros 3 textos, mientras que esta tendencia pareciera diversa en los últimos 3, llegando en el Tratado de las armas a una preferencia casi total por la finalización -dat. El caso del Cancionero de Estúñiga, cuyos rasgos aragoneses son bien conocidos (es fuente del DICCA-XV), acaso permita inferir que en los otros dos textos esa grafía pudiera ser también imputable al copista. En textos castellanos de autores o copistas aragoneses, de hecho, se observa una preferencia por -dat. Tómese el caso de la Traducción de la Eneida de Enrique de Villena -como la mayoría de los textos de Villena, fuente del DICCA-XV—, donde tenemos una incidencia de 1922 voces terminadas en -dat, frente a solo 50 en -dad (es decir, una preferencia del 97,5\%). 
2a) y angels (ATF 2e). Podríamos sumar dretxa (ATF 3h), probable interferencia del aragonés drecho o del catalán dreta, la cual posibilita un hemistiquio más natural («Pues bien a la dretxa...», o óoo óo) y sin metaplasmos, a diferencia del que hubiera resultado de deretxa («Pues bien a la deretxa», oo òoo óo), con un ictus raro en tercera y, además, en partícula átona.

Para concluir, un último y sugerente detalle: resulta curioso el resultado que obtenemos si contamos la cantidad de interferencias (DGR: 31, ATF: 47) y las dividimos en catalanas y/o aragonesas. En DGR solo 7 pueden remitirse a un rasgo puramente aragonés - aunque, como dijimos, es probable que la interferencia ingrese por vía del mismo castellano que se hablaba en la corte-, mientras que en ATF el número asciende a 21 .

\section{El posible origen zaragozano de Pere de Civillar}

Quisiéramos finalizar con algunas reflexiones sobre el autor de ATF. La gran cantidad de aragonesismos en la composición de Pere de Civillar nos ha planteado el problema del origen de este poeta, que hasta ahora se consideraba castellano. Martí Grajales (1894) advertía, por una parte, que no lo encontró en ningún registro de argenters valencianos y que, portanto, debió de vivir poco en Valencia. ${ }^{65}$ Sanchis Guarner (1979: 13) señalaba solo que «són en castellà el poema presentat per "un castellà sens nom", i el de Pere de Civillar, el qual, potser, també ho seria». Ferrando Francés (1983: 202), por su parte, propuso un origen castellano dada la poca probabilidad de que un artesano valenciano manejara el idioma con la soltura necesaria para confeccionar una pieza poética. ${ }^{66}$ Esta argumentación, aunque totalmente atendible, no prueba que

65 Martí Grajales (1894: 66) señala: «No debía ser valenciano o debió residir muy poco tiempo en esta Ciudad. Los plateros elegían anualmente para consejeros á dos maestros de su profesión. Desde 1445 a 1520 no vemos entre los nombrados a Pedro de Civillar, quien tampoco figura en el libro I de Tacha real del año 1513».

66 En palabras de Ferrando Francés «Pere de Civillar era probablement castellà, car resulta poc explicable que un menestral valaencià empràs el castellà en una época en què sols alguns nobles i rarament algun burgès feien esporádics exercicis de poliglotisme poètic en aquesta llengua». 
fuera castellano: solo permite descartar su origen valenciano. Destáquese asimismo que, de ser el caso, deberíamos asumir que el nombre aparece en $L V$ catalanizado (Pere y no Pedro), lo cual sería perfectamente posible.

A estas argumentaciones habría que agregar la ordenanza dada por Juan I el 20 de diciembre de 1392, en la que además de confirmar, ampliar y modificar las ordenanzas previas, obligaba a todo argenter, tanto en Aragón como en Cataluña, a inscribirse en la cofradía de Sant Eloy, ${ }^{67}$ lo cual implicaba participar anualmente en las elecciones de los integrantes del órgano de gobierno. En este sentido, el hecho de que Pere de Civillar no esté documentado parece una prueba bastante sugerente como para excluir la hipótesis de un origen valenciano. Sin embargo, en el estudio sobre orfebrería valenciana de Sanchis Sivera (1923: 52), se ofrece un documento latino fechado el 20 de febrero de 1469 donde se registra, entre una lista de argenters que participaron de la elección de "taxatores», «marquatores», etc., a un Petrus de Sivilla. Tras la lista de argenters que participan en la elección y de la transcripción del acta en latín, el documento vuelve a mencionarlo así: «Dictus Blasus Marti que en la tacha no consent, et Jacobus Gatola no consent empero quey vol...a so voluntat hi vol contribuhir...li paura, e Pedro de Siuilla tambe.- Testes ídem» (1923: 53). Dada la normal oscilación ortográfica $c / s$, solo quedaría por explicar la $r$ final, posible agregado del cajista, para postular una coincidencia entre Pere de Civillar y Pedro de Sivilla. El patronímico explicaría, además, el manejo del castellano por parte de un platero.

Ahora bien, la cantidad de aragonesismos podría indicar otra posibilidad. Es cierto que el resto de los poemas castellanos presentan rasgos o interferencias aragonesas: como ya dijimos, por un lado, el castellano que se habla en la corte de Valencia (que es el que manejan Castellví o Barceló) presenta rasgos aragoneses, por otro, el catalán valenciano tiene como adstrato el aragonés. En este sentido, mientras que las interferencias aragonesas en el poema de Castellví pueden fácilmente

67 Véase Sanchis Sivera 1922: 2-3 y, más recientemente, Martínez Vinat 2018: 472, quienes reenvían al documento en cuestión Archivo de la Corona de Aragón (ACA) Reg. 1902, ff. 116v-119r. 
explicarse por el mismo castellano de corte que, en tanto noble, él conocería, las del poema de Civillar, más numerosas y consistentes, no pueden explicarse en razón de su estatus sociolingüístico si asumimos, siguiendo a Ferrando Francés, que es castellano. Podría plantearse la hipótesis de que esos aragonesismos, como sabemos que sucede con varias de las interferencias catalanas, se incorporasen en la etapa de impresión: excepto que postulemos un cajista aragonés - lo cual no es imposible, dada la gran cantidad de migración entre una y otra zona-, es de suponer que esas interferencias se introducirían por vía del valenciano. Sin embargo, la dental oclusiva - $t$ que en ATF encontramos en devotión (3d), perfectión (4f), coronatión (4h), salvatión (4i, 5f), discretión (5i) no se encuentra en términos catalanes en -cio ni una sola vez en el resto del incunable, lo que podría ocurrir al menos otra vez si la interferencia fuera del cajista. ${ }^{68}$ En los otros poemas castellanos, además, se registra una vez un término en -ción (obligación, $\mathrm{n}$ 으, 2g), el cual recibe grafía castellana. Habría que agregar otros casos que serían plausibles de recibir grafía en - $t y$, sin embargo, aparecen en su forma castellana: constancia (DGR, 5c), permanencia ( $n$ ㅇ 7, 2f), presencia ( $\mathrm{n}$ $7,2 \mathrm{~h}$ ), reverencia ( $n-7,2 \mathrm{i})$. Así, el hecho de que esta interferencia $-t$, observable también en scientia y proffetía (ATF, 3h), se concentre en este poema permite deducir que pertenece al autor. Acaso esta grafía podría tratarse de un cultismo latino; sin

68 Hemos buscado en el CICA los equivalentes catalanes de todos estos términos (i.e. devocio, perfeccio, coronacio, salvacio, discrecio) junto a una posible realización en -tio, y obtuvimos los siguientes resultados: devotio (2, valenciano), devocio (360); perfectio (34), perfeccio (92); coronatio (1), coronacio (33); salvatio (0), salvacio (89); discretio (1), discrecio (119). Una tan baja incidencia de la realización grafemática de estos términos catalanes en - $t$, casos quizá explicables desde un error de lectura común entre $c / t$, lleva a suponer la poca probabilidad de que esa transferencia se introduzca por vía del catalán o, más específicamente, del valenciano. Es de notar, asimismo, que el verso 3a de esta composición lee "consolación», único caso de terminación en -ción en todo el poema. Dado que 7 de 8 casos presentan la forma en -tión, y que los otros casos en los que en castellano se esperaría $c$ presentan $t$ (scientia 3 h, proffetía $3 \mathrm{~h}$ ), suponemos que es «consolación» el término que se aparta del idiolecto del autor. En efecto, esa c podría explicarse ya sea por la tan común confusión de tipo móvil entre $c$ y $t$, ya sea por interferencia del catalán consolaciò. En el CICA, siglo XV, se registran 366 casos de consolaciò, frente a solo 4 de consolatió. No es descabellado suponer, por tanto, que se haya producido una interferencia por vía del valenciano que resultó, de hecho, en una grafía más castellana que la que presentan el resto de los términos en rima. 
embargo, la presencia en el resto del poema de otros rasgos propios del aragonés no rastreables en el valenciano (como el pretérito del verbo ser en primera persona fue y no fui), nos conduce a contemplar la posibilidad de que se traten todos, de hecho, de aragonesismos y, por tanto, a proponer como hipótesis a tener en cuenta un origen aragonés del poeta argenter. Este origen explicaría tanto el problema de que, siendo artesano, maneje el castellano con solvencia para crear una composición poética, como la mayoría de los rasgos lingüísticos del poema. A este respecto, Frago Gracia (1991: 129) destaca:

[...] en Zaragoza antes de que la decimoquinta centuria viera su fin la lengua de comunicación escrita, y presumiblemente también oral, ya era aquel castellano en variable medida teñido de aragonesismos de toda índole, que de tal guisa se había configurado merced a determinados condicionamientos históricos. ${ }^{69}$

Aclara también Frago Gracia que es el origen sociolingüístico del sujeto enunciador, no solo cultural sino también generacional, el que explica diversos grados de castellanización en textos escritos en el mismo año:

a mayor edad del sujeto hablante se espera, en principio al menos, un mayor apego a los usos lingüísticos en la niñez asimilados, un más acusado tradicionalismo idiomático [...]De igual modo que a mejor formación intelectual del individuo, más fuerte seria la atracción convergente derivada de su contacto con la cultura castellana, especialmente en su variante libresca o literaria (1991: 122).

Acaso sea menester señalar que los argenters gozaban, como es de esperar por el tipo de trabajo y sus clientes, de un alto estatus económico (Gómez de Valenzuela 2017: 19-20) y, por tanto, tendrían acceso a una buena educación.

69 Continúa el lingüista: «Que hubo gradación en la coherencia normativa por motivos estilísticos, culturales, generacionales y de procedencia local, atingentes a los distintos hablantes-escribientes, ninguna duda cabe. [...] Pero, aun no olvidando la existencia de diferencias internas en el habla de este núcleo capitalino, parece seguro que la castellanización se inició en él antes y progresó con celeridad mayor que en el medio rural de todo el valle del Ebro, para el que cabe sospechar se constituyó en su referencia modélica». 
Siguiendo esta hipótesis, intentamos rastrear alguna mención de nuestro argenter en documentos zaragozanos. Esta ciudad, como prueba Gómez de Valenzuela (2017: 26), era un importante centro de argentería, cuyo prestigio atraía no solo a mercaderes sino también a aprendices de diversas zonas de la Península. Es de destacar, asimismo, la gran circulación de plateros entre Zaragoza y Valencia, generalmente por viajes de negocios (2017: 23). Así, en los documentos sobre plateros zaragozanos que ofrece Gómez de Valenzuela hemos encontrado el registro de un Pedro de Villar, perteneciente a una familia de argenteros de la ciudad. ${ }^{70} \mathrm{El}$ primer registro de su nombre es el testamento de su tío, en 1477 , en el que señala que dejará sus pertenencias a su hermano Johan, y si este muriera a su «nieto» -i.e. sobrino- Pedro de Villar y, si este muriera, a su hermano Johan o en su defecto a Catalina -madre de Pedro y Johan.$-{ }^{71}$ Pedro aparece también registrado en 1484, 1492, 1496 y 1498 (2007: 203, 278 y 308). Aunque se trate de una mera hipótesis, sin ninguna prueba concluyente, creemos que la identificación del poeta de $L V$ con Pedro de Villar podría ser posible, pues la variante en el apellido se explicaría desde un error de imprenta: ya sea una lectura errónea por parte del cajista, un agregado de tipos, etc. Además, señala Gómez de Valenzuela (26) cómo muchos maestros zaragozanos enviaban a sus hijos a adiestrarse en el oficio con colegas de su misma ciudad o de otras, como ocurría con barceloneses que iban a Zaragoza y viceversa. Dado que, por un lado, en un documento de 1464 se registra a los padres de Pedro (2007: 308), el argentero Paulo de Villar y Cathalina, vendiendo una propiedad como marido y mujer y que, por consiguiente, su matrimonio tuvo que celebrarse antes - Gómez Valenzuela no ofrece datos sobre sus capitulaciones - y que, por otro, su tío lo menciona como heredero en 1477, es de suponer que para 1474 fuera un joven mozo. No sería extraña

70 Según hemos corroborado, esta familia no aparece en los registros de Abizanda y Broto (19151917), ni en los trabajos de documentación posteriores de Cabezudo Astrain (1961) y de Llorente (1977).

71 Gómez de Valenzuela 2017: 150, documento 94. El padre de Pedro, Paulo de Villar, registrado en un documento de 1464 junto a su mujer Cathalina, y luego solo en 1472 y 1473, ya debía haber fallecido, lo que explica que Miguel mencione al hijo de Paulo en segundo lugar. En la capitulación matrimonial de Pedro (1496), queda claro que Cathalina es viuda. 
la posibilidad, por tanto, de que Pedro de Villar fuera enviado a Valencia, otro gran centro de argentería, durante sus años juveniles, los cuales podrían acaso haber coincidido con el certamen de 1474 o que, de ser mayor, fuera a Valencia en un viaje de negocios. Ambas posibilidades explicarían la falta de registros de este argenter en Valencia.

La identidad de Pere de Civillar, acaso castellano, acaso aragonés, queda por ahora como una incógnita: tanto el complejo panorama lingüístico del poema, como los datos documentales recabados, sugerentes pero no probatorios, impiden arribar a una conclusión satisfactoria. Consideramos, sin embargo, que la posibilidad de que no sea castellano debe ser atendida: acaso sea ese el aporte principal del apartado anterior. Esperamos, asimismo, que el trabajo llevado a cabo en estas páginas haya contribuido al estudio y valoración, tanto ecdótica, como poética y lingüística, de los dos poemas en arte mayor castellano de LV. Ojalá la nueva edición crítica que proponemos a continuación allane el camino a nuevos y ricos trabajos, no solo sobre estos poemas, sino también sobre Les trobes en lahors de la Verge Maria en general, fructífero campo para estudiar el valenciano medieval. 


\section{APÉNDICE EDICIÓN CRÍTICA DE DGR [ID4650] Y ATF [ID4652]}

En la siguiente edición cotejamos el texto de Les trobes (LV) con las ediciones de Sanchis Guarner (1979, SG) y Ferrando Francés (1983, FF), señalando en nota las diversas elecciones editoriales. En nuestra edición:

a. Se desarrollan las abreviaturas indicándolas en cursiva.

b. Se regularizan $u$ y $v o b$, como también la $i, j$ e y según su valor vocálico o consonántico. Conservamos la variante gráfica del nexo coordinante hi/y (véase punto h).

c. Se mantienen las dobles consonantes.

d. Se trascriben las grafías $3, z$ y $\int$ comos.

e. Se sistematiza el uso de mayúsculas en nombres propios, así como en las referencias divinas, sean nominales o pronominales. En las referencias a la Virgen, dada la gran cantidad de epítetos y de referencias a su virginidad, solo incorporamos mayúscula cuando Virgen se utiliza en tanto referencia nominal.

f. Se utilizan criterios actuales de puntuación y acentuación, así como de unión y separación de palabras. La separación se señalará con apóstrofe. La puntuación, es pertinente aclarar, tiene en cuenta que las semiestrofas del arte mayor tienden a ser una unidad enunciativa.

g. Se reemplaza el uso de la vírgula entre ambos hemistiquios del verso por un espacio que indica la pausa medial de la cesura.

h. Se mantienen las interferencias lingüísticas provenientes del catalán y el aragonés, excepto en los casos que conduzcan a confusiones.

En el aparato de notas se señala, cuando corresponda, si la lección del impreso presenta algún error mecánico propio de la imprenta. Se señalarán, asimismo, los casos de interferencias lingüísticas, reenviando ya sea a la bibliografía correspondiente, ya sea al apartado de nuestro estudio donde hemos profundizado en el tema. Aunque estas notas sean de naturaleza evidentemente diversa, hemos decidido no dividir el aparato en dos nivelas pues en muchas ocasiones es difícil distinguir si la lección que se transmite en el incunable se trata de una errata mecánica o de una interferencia lingüística. 

de la Verge Maria, en lengua ${ }^{72}$ castellana

\section{I}

Del gran Redemptor madre hi esposa, ${ }^{73}$ consuelo, reparo de los peccadores; ${ }^{74}$

del muy Soberano espijada rosa, ${ }^{75}$

en quien el Eterno se huelgua y reposa, ${ }^{76}$

5 mejor de las buenas, $y$ an de las mejores. ${ }^{77}$

De Dios alabada: si poco te alabo, si mi lengua estando el tu lohor corre, ${ }^{78}$

72 Rúbrica] lengua FF] leygua LV, llengua SG. Error mecánico: cambio o sustitución de tipos móviles.

73 1a. hi LV FF] i SG. Interferencia grafemática o léxica. La $h$ expletiva o inorgánica es frecuente en textos aragoneses del XV ante vocal. Véase Arnal Purroy \& Enguita Utrilla 1993: 55, Gómez-Fargas 1989: 28 y Giralt Latorre 2018: 12. Según Alvar (1987: 41) también es común en catalán: aunque en el Vocabulari hí no se registra como variante del nexo e, en el CICA, s. XV, se registra 1055 veces, 22 en LV. Hí como nexo, por tanto, era usual en catalán y podría ser aquí una interferencia morfemática (véase 3e, 4e. y $A T F$ 1c).

74 1b. peccadores LV FF] pecadores SG. Interferencia catalana o aragonesa a nivel grafemático. Todas las ocurrencias de esta voz en $L V$ (peccador/peccadors) presentan doble -cc. En el CICA, s. XV, el término peccador/s aparece registrado 285 veces, frente a 16 de pecador/s. En cuanto al aragonés, señala Alvar que la grafía doble cc tiene, con poca frecuencia, valor /k/ (1987: 41); sin embargo, según observamos en el DiCCA-XV (s.v. pecador), la forma grafemática con doble cc era más frecuente: pecador -ora (39), peccador -ora (90).

75 1c. espijada FF] espiiada LV, espejada SG. Conservamos la lección espijada, como FF, pues el término es fruto de una interferencia. Resulta problemático, sin embargo, definir si se trata de una interferencia del catalán espill (i.e. espejo) operada sobre la hipotética lección espejada -así como edita SG-, o de un trueque entre $g / j$ para representar el fonema prepalatal fricativo sonoro /ž/ propio del aragonés, que habría operado sobre la hipotética lección original espigada. Para más disquisiciones sobre este locus véase el estudio, apartado 2.1 .

76 1d. huelgua LV] huelga FF SG]. Interferencia grafemática aragonesa de - $u$ superflua: la gu tiene valor /g/ ante - $a$ (véase Giralt Latorre 2018: 12 y Enguita Utrilla 2009: 119-120), caso análogo a qu con valor / $\mathrm{k}$ / (véase $1 \mathrm{~h}$ y $2 \mathrm{j}$ ). Este rasgo se nota también en el catalán (Alvar 1987: 18), véase especialmente Vocabulari s.v. folgar/folguar.

77 1e. an LV FF] a(u)n SG. Se trata de un arcaísmo incorporado por requerimientos silábico acentuales. Respecto del problema de hipermetría que genera la enmienda de SG véase nuestro estudio, apartado 1.2 .

78 1g. lohor LV] loor FF SG. Interferencia grafemática aragonesa de $h$ expletiva, usual también en interior 
yo bien lo comienço mas nunqua l' acabo, ${ }^{79}$

qu'enprender lo arte por legar al cabo ${ }^{80}$

es querer fundar babilónica torre.

II

Amiga de Dios en cell siglo creada ${ }^{81}$

y antes que naciesses por Dios escogida,

nasciendo 'nel ventre, nuncha manzillada,

nasciendo 'nel mundo, muy glorifficada, ${ }^{82}$

15 de todas virtudes toda guarnecida.

de término (Arnal Purroy \& Enguita Utrilla 1993: 55; 1995: 163). En el CORDE, s. XV, encontramos 26 casos de lohor, de los cuales 15 se dan en textos de influencia aragonesa - cartas de Fernando el Católico, Triunfo de amor, Cancionero de Palacio, Libro del Tesoro de Girona-, mientras que en el CICA las únicas dos incidencias son de $L V$. En catalán no se registra esta - $h$, véase Vocabulari s.v. Iloor, loor. En el DiCCA-XV encontramos ambas formas gráficas, registrándose mayores casos de la grafía castellana y catalana pura: lohor (60), loor (112).

79 1h. Nunqua I' acabo] nunqual acabo LV, nunque I.acabo FF, nunca l'acabo SG. Interferencia grafemática aragonesa: $u$ superflua tras consonante velar / $/$ que afecta en mayor medida al final de palabra. Rasgo característico de los escribas aragoneses en los siglos XIV y XV, véase Enguita Utrilla 2009: 119-120 y Alvar 1987: 18. Se registra en el DICCA-XV como variante formal con 193 casos.

80 1i. qu'enprender FF] quen prender LV que emprender SG | Io] Catalanismo (Vocabulari s.v. lo) o aragonesismo: en aragonés y en leonés se conservó la forma lo para el nominativo singular (Menéndez Pidal 1952: 262). Desde León hasta Cataluña las formas el y lo estaban en pugna como artículo masculino singular, mientras que muy temprano en Castilla se optó por el (Lapesa 1980: 185-186). Se halla lo como artículo en los poemas de Centelles («lo paraís», no 1, 1d y «lo mon», 4i) y Corella («lo sepulcre», n으 2, 1h). | legar LV FF] Ilegar SG. El uso de la / con valor // es, según Menéndez Pidal (1950: 54), típico de la zona de Aragón y Cataluña. Para más ejemplos: Arnal Purroy \& Enguita Utrilla 1993: 55, Gómez-Fargas 1989: 30, Alvar 1987: 30. Véase nota 4d.

81 2a. cell] cel LV, el FF, (c)el SG. Provenzalismo - forma apocopada del demostrativo aycell, introducido en lugar de aquel para respetar el patrón rítmico óooó (más detalles en el apartado 1.2)-. Reponemos la segunda / para que sea claro el origen provenzal del término: a lo largo de $L V$ se observa la vacilación ortográfica de las palatales tanto en el caso del cell demostrativo, como en cel en el sentido de cielo. Para detalles sobre la doctrina que subyace a este verso, que la enmienda de FF y SG contradicen, remitimos también al apartado 1.2.

82 2c. glorifficada LV] glorificada FF SG] Interferencia grafemática aragonesa. Según Alvar (19581959: 202) y Arnal Puyol \& Enguita Utrilla (1993: 58) es frecuente el agrupamiento de $f$ en posición intervocálica en textos aragoneses. En el CORDE, s. XV, los únicos 3 casos de glorifficada se registran en el Cancionero Castellano de París (uno de los textos del corpus de DICCA-XV). 
Pues todos tus actos siempr'an merecido, ${ }^{83}$

y jamás cessaron tus obras perfetas, ya nos maravilla, si tanto has subido, que todo 'I restante de Dios has vencido:

20 ángeles mil, patriarquas, profetas. ${ }^{84}$

III

[f. 8v] Palma, ciprés, flor, tálamo, nube, luna, ${ }^{85}$

templo, gozo, vida, fe, luç y luzero, ${ }^{86}$

cedro, nardo, mirra, persona comuna:

cent mil son tus nombres mas tú, sin par, una; ${ }^{87}$

25 sin par, hi segunda después del Primero. ${ }^{88}$

El qual encarnado de tu carne pura ${ }^{89}$

io quánt pura 'I alma quánt santa sería!

Pues bien a la dretxa de Dios te figura

Davit, rey profeta, maguer creatura, 90

83 2f. siempr'an] por siempran LV, por siempr.an FF, por siempr(e) han SG. Como aclaramos en el apartado 1.2, este verso resulta hipermétrico. La preposición por atenta contra el esquema isorrítmico del arte mayor y fue probablemente agregada por el cajista. Enmendamos para reponer el patrón rítmico.

84 2j. patriarquas LV FF] patriarcas SG. Interferencia grafemática aragonesa: $-u$ inorgánica. No se registra en CICA, aunque sí en el DICCA-XV. Véase $1 \mathrm{~h}$.

85 3a. ciprés FF SG] apres LV. Se trata de una lectio facilior del componedor: dada la ejecución escrita de la $c$ unida a la $i$, seguramente leyó una $a$, confundiendo el término con aprés, adverbio del valenciano antiguo (Giralt Latorre 2018: 17).

86 3b. luç FF SG] Inç LV. Error mecánico: tipo volcado.| luzero FF SG] luzcro LV. Error de selección de tipo (el componedor toma una e por una c) frecuente en el impreso (véase 4a).

87 3d. cent LV FF SG] catalanismo (véase Vocabulari s.v. cent). En el CORDE encontramos 6 incidencias en el siglo XV, la mayoría de documentos de Barcelona y Zaragoza.

88 3e. hi LV FF] i SG. Véase 1a. | después FF SG] despies LV. Error por cambio de tipo móvil.

893 3f. qual FF SG] qnal LV. Error mecánico de tipo volcado.

90 3i. Davit LV, SG, FF] Señala Lapesa (1981: 476) el típico uso catalán, valenciano y murciano de la $t$ final, así como la pronunciación de la $d$ final de palabra ensordecida con cierta tensión que la aproxima a /t/. Según Giralt Latorre (2018: 12) esta característica gráfica se da también en el aragonés; GómezFargas (1989: 27) ofrece numerosos casos de un escriba aragonés, entre ellos la voz Davit. Véase nota ATF 4c. 
Revista de Cancioneros Impresos y Manuscritos, 11 (2022), pp. 148-211

viendo 'I Creador que de ti nascería. ${ }^{91}$

IV

¿Qué viera después el gran evangelista ${ }^{92}$

en ver tu corona de las dotze estellas? ${ }^{93}$

¿Qué vieren los homes? ¿Qué más vio 'I salmista

viendo que sallías, aurora prevista, ${ }^{94}$

35 a etxar las teniebras con luç hi vençellas?95

91 3j. de ti FF SG] datí LV. Error por cambio de tipo. | nasceria FF] nascria LV SG. Dado que a lo largo de $L V$ se eligen las grafías $s c$ para el verbo nacer, suponemos que se omite el tipo móvil vocal. Alvar (1958-1959: 201) atribuye a una solución etimologizante el uso del grupo sc con valor /š/] en textos aragoneses medievales.

92 4a. evangelista FF SG] cuangelista LV. Error mecánico: cambio de tipo.

93 4b. ver tu FF SG] ver te LV. Este verso y los que siguen hacen referencia al pasaje del Apocalipsis $(12,1)$ donde se aparece una mujer vestida de sol, con la luna a sus pies y una corona de doce estrellas sobre su cabeza. | dotze FF SG LV] Catalanismo o aragonesismo. La grafía tz corresponde al sonido /dz/ - africado alveolar sonoro- en catalán (GEIEC 2.7). Arnal Purroy \& Enguita Utrilla señalan a dotze como un numeral propio del catalán (1993:64), lo cual corroboran las 186 ocurrencias en el CICA durante el s. XV. Señala Alvar que el grupo consonántico $D^{\prime} C$ se identifica en aragonés con $T^{\prime} C$, y como ejemplo ofrece el caso de dotze. En el DICCA-XV la variante formal más usual de doze, con 73 casos, es dotze. Señalemos, por último, que en CORDE durante el s. XV, tenemos 51 incidencias de la voz, todas en documentos relativos a Zaragoza, Aragón en general o Cataluña. | estellas LV] estrellas SG FF. Aunque puede tratarse de un error mecánico (omisión de tipo), es probable que se trate de una interferencia del catalán estela/stella/estella (véase Vocabulari s.v. estela, donde se registra la variante estella; véase también s.v. ceguetat, cristifer, estella de mar). En el CICA estella se registra en 7 ocasiones, aunque estela en 106. Nótese cómo en el verso 6a se repite la voz estrella, sin interferencias.

94 4d. sallías LV] sal.lías FF SG. El empleo de las grafías // con el valor no palatalizado de simple / es muy común en catalán (GEIEC, 2.2.3), como argumenta Ferrando Francés (1983: 300) para el caso de sallió (véase Vocabulari s.v. sallir). Para más ejemplos: Gómez-Fargas (1989: 31). Según Alvar es también un rasgo navarro y aragonés, común en la documentación medieval aragonesa (Arnal Purroy \& Enguita Utrilla 1993: 55), aunque la confusión existió también en Castilla y León (1987: 42). Véase DGR 1i.

95 4e. A etxar FF SG] Aetxar LV. Interferencia del catalán: se representa el valor fónico /ĉ/ con las grafías tx como en el catalán (véase 3h).| teniebras LV FF SG] Es difícil definir si esta forma tuvo interferencia del catalán tenebra pues en el CORDE en el s. XV se registran 77 casos en su forma plural y 38 en singular. El término castellano variaba bastante durante el s. XV: el CORDE registra 113 casos de tiniebra y 93 de tiniebla. Si bien el trueque entre $r$ y $l$, en la misma sílaba, tras consonante es usual al sur de León (Lapesa 1980: 492), esto puede deberse al carácter arcaizante del aragonés por asimilación del latín tenebrae: en DiCCA-XV se halla tenebra (2), teniebra (7), tinebra (1), tiniebla (6), tiniebra (35). La vacilación en las vocales e/i átonas se observa en castellano (Menéndez Pidal 1952: 67; Lapesa 1980: 
Luç de la qual sabes lo mutxo que sabe, ${ }^{96}$

luç de la qual puedes todo quanto quieres,

luç de la qual gracia jamás no te cabe, luç de la qual sola pienso que te alabe, pues otri desir no podría quál eres. ${ }^{97}$

$\checkmark$

El sol eres tú, do fizo Dios estancia, de quien el Esposo lucido saliera mas virgen dexara, ni vergen constancia ${ }^{98}$ passando per ella Divina Sustancia ${ }^{99}$

45 la qual ningún danio jamás consentiera. Pues tú, madre virgen, tú virgen doncella, tú virgen prenyada, tú virgen parida, ${ }^{100}$ tú la melezina de nuestra querella, tú sola y tu Fijo fuestes quitos d'ella:

50 mas Él y tú 'n Él la pagastes complida. ${ }^{101}$

209) y aragonés (Zamora Vicente 1985: 219, Giralt Latorre, 2018: 13), aunque en CORDE solo se hallan 9 casos de teniebla durante el siglo XV | hi LV FF] i SG. Véase 1a.

96 4f. mutxo LV FF SG] Interferencia grafemática del catalán (véase verso 3h).

97 4j. otri LV, FF, SG] Aragonesismo. Así lo señalan Enguita Utrilla (2009: 128) y Arnal Purroy \& Enguita Utrilla (1993: 63). En el DiCCA-XV s.v. otri encontramos 95 incidencias. En el CORDE, se registra en 48 textos en el s. XV, la mayoría de los cuales son documentos regios o notariales zaragozanos (27) o textos literarios con consabidos aragonesismos como el Cancionero de Íxar o Grimalte y Gadissa.

985 c. vergen LV FF SG] catalanismo. Dado que el término catalán verge es uno de los más frecuentes de $L V$, probablemente la forma vergen proceda de una interferencia catalana (Vocabulari, s.v. verge). En DiCCA-XV hállase vergen (6), virgen (262). En el CORDE, s. XV, hay solo 7 incidencias de la voz vergen, en dos textos que son parte del corpus de DICCA-XV (Crónica troyana y Recetario de Gilberto).

99 5d. per LV SG] por FF. Catalanismo. Véase Vocabulari s.v. per, Pompeu Fabra 2006: 120 y Giralt Latorre 2018: 17. Se registra su uso también en el aragonés, como lo atestigua el empleo de per en la frase "per astí» (Zamora Vicente 1985: 275) y el DICCA-XV en 24 incidencias s.v. por.

100 5g. prenyada LV FF SG] Aunque puede tratarse de una interferencia grafemática aragonesa (véase 5e), la existencia del catalán prenyada (véase Vocabulari) nos inclina a suponer que es un catalanismo. 101 5j. mas Él y tú 'n Él] mas el ytun el LV, más Él y tú en Él FF SG. 


\section{VI \\ Endreça \\ De los patrïarchas deseada estrella, \\ d'ángeles ornada, de santos servida: \\ $¡$ ¡ quán sobre todos Dios te crió bella \\ qu' Él no aviendo madre, ni tu siendo aquella, \\ 55 d’ Él fueras ahun la más alta y lucida! $!^{102}$}

[f. 31v] Resposta de mestre Pere de Civillar, argenter, en lahor de la Verge Maria, tirant a la Joya

।

Al tempo que Febo su gran claridat ${ }^{103}$

fue demostrada en el centro profundo,

muy grande teniebra hi escuredat, ${ }^{104}$

por nimio discurso de antigüidat, ${ }^{105}$

102 6e. ahun LV FF] aún SG. Según observamos en el DiCCA-XV (s.v. aun) las variantes grafemáticas de aun en el castellano aragonés incluían de manera preferencial el uso de una $h$ superflua: ahun (1469), aun (836), hahun (8), haun (166). Sobre el uso de la $h$ superflua o expletiva véase nota al verso $1 \mathrm{~g}$.

103 1a. tempo LV FF SG] Probable interferencia catalana, véase Vocabulari s.v. temps. En el CORDE, $\mathrm{s}$. $\mathrm{XV}$, se registran 12.184 casos de tiempo y 20 de tempo, en 4 textos. Sin embargo, 15 de estos casos pertenecen a Villasandino, de los cuales 13 son poemas gallegos (dado el usual uso del gallego por parte de Villasandino, los otros dos pueden considerarse galleguismos). Los restantes registros, en Mena y Palencia son probables cultismos. Acaso se trate de un aragonesismo, pues mantiene la forma latina tempus (en DiCCA-XV hay 2 incidencias). La oscilación en la diptongación de e era frecuente tanto en catalán como aragonés (Casanova 2011: 208 y Parrilla 2017: 264), aunque el catalán tendiera a eliminar el diptongo (Lleal 2003: 49). | claridat LV FF SG] Interferencia aragonesa - $t$ (véase nota DGR 3i), se repite en 2j. Aunque se registra el término en castellano (CORDE 263 casos, muchos de los cuales en textos aragoneses) como variante de claridad (CORDE, 535 casos), la mayor incidencia en el DICCA-XV (claridat 17 ocurrencias, claridad 15), sumado a los numerosos rasgos aragoneses que tiene ATF nos inclinan a suponer una interferencia aragonesa. Respecto a la - $t$ en el aragonés, como resultado o no de apócope extrema, véase Giralt Latorre 2018: 12, Arnal Purroy \& Enguita Utrilla 1993: 62 y Zamora Vicente 1985: 248-250.

104 1c. teniebra LV FF SG] Véase nota DGR 4e. | hi LV FF] i SG. Véase DGR 1a. | escuredat LV FF SG] aunque podría ser un catalanismo puro (véase Vocabulari s.v. escuredat), es más probable que se trate una interferencia operada sobre escuridat, aragonesismo registrado en el CORDE en 55 casos (oscuridat, 11) y en el DICCA-XV en 7. Véase nuestro estudio, apartado 2.1.

105 1d. discurso SG] discurço LV FF. | Antigüidat] antiguidat LV FF SG. Interferencia del equivalente 
5 de certo quedó en las partes del mundo. ${ }^{106}$

Yo conquistando mi vano placer, ${ }^{107}$

dormiendo ' $\mathrm{n}$ un letxo con bellos cotxones, ${ }^{108}$

fui transportado en un lindo verge $\left.\right|^{109}$

muy oloroso, de grande valer,

10 segund que verés en mis conclusiones.

II

Fallándome dentro en esta foresta

toda 'nredada de lindos gesmines, ${ }^{110}$

catalán (véase Diccionari de la llengua catalana de l'Institut d'Estudis Catalans s.v. antiguitat y los ejemplos del Vocabulari s.v. anciá, ennobleir, envilanir, indispost, novelletat, prim). Nótese que en el CORDE (s. XV) se registran numerosas incidencias de las variantes antigüedad y antiguedat, mientras que antiguidat se registra solo una vez, en un documento castellano de Barcelona. Como planteamos en el apartado 2.1, la interferencia acaso opere sobre un ya aragonizado antiguedat, registrado en CORDE 18 veces y en DICCA-XV 4.

106 1e. certo LV FF SG] La voz tiene una incidencia muy baja en el CORDE: de las 32 entradas registradas en el s. XV, solo 3 corresponden a castellano (el resto, son textos latinos). El castellano cierto, en cambio, se registra en 3010 casos. Podría tratarse, por tanto, de una interferencia lexical del catalán cert (véase s.v. Vocabulari), o de un aragonesismo, dado que la voz certo se registra en el DICCA-XV como variante gráfica (s.v. cierto). Las tres ocurrencias del CORDE, además, se dan en textos con rasgos aragoneses (2 documentos de Fernando el Católico y el Cancionero de Estuñiga). Asimismo, como ya mencionamos, la oscilación en la diptongación de e era frecuente tanto en catalán como aragonés (Casanova 2011: 208 y Parrilla 2017: 264), aunque el catalán tendiera a eliminar el diptongo (Lleal 2003: 49). Acaso pueda también postularse que esta reducción del diptongo fuera fruto de una regularización gráfica de Fenollar, véase estudio 2.1.

107 1f. mi vano] con mi vano LV FF SG. Como analizamos en el apartado 1.2, se trata de un verso hipermétrico que es preciso enmendar.

108 1g. letxo LV FF SG] cotxones LV FF SG] Interferencia grafemática: se representa el fonema de valor africado /ĉ/ según la ortografía del catalán $t x$. Véase DGR 3h.

109 1h. Fui] fue LV, FF, SG. Dado el sentido de la semiestrofa, esperaríamos aquí un verbo ser conjugado en 1 o persona singular. Podría aducirse que se trata de una errata por confusión de tipos móviles, sin embargo, dada la cantidad de interferencias aragonesas en el poema, es más probable que se trate de un aragonesismo. En aragonés el perfecto del verbo ser es fue(y) (Zamora Vicente 1985: 274). Aunque se trate de un probable rasgo dialectal, enmendamos para evitar la confusión con la forma castellana en 3era persona, que en ese contexto podría leerse aplicada a «letxo».

1102 b. toda 'nredada LV FF] (e)nredada SG. Puede tratarse o bien de una contracción introducida por el poeta en situación de sinalefa (véase $D G R 2 \mathrm{f}$ e infra $3 \mathrm{~g}$ ), o bien de una interferencia aragonesa: las 
fue aparecida la Virgen honesta

en un carro triunfante, mutxo bien puesta,

cercada de àngels e de serafines, ${ }^{111}$

todos lohando su grande clemencia. ${ }^{112}$

De su resplendor cahí en el suelo, ${ }^{113}$

levanteme de presto por ver su potencia,

mirando su gesto y más excellencia,

20 de tal claridat que li diere el cielo. ${ }^{114}$

III

[f. 32r] Aquesta es la madre de consolación, inmaculada, del todo perfeta.

vocales átonas en posición inicial suelen perderse con frecuencia en el aragonés (Zamora Vicente 1985: 219) | gesmines LV FF SG] interferencia léxica del equivalente catalán gessamí (véase s.v. en Vocabulari).

111 2e. àngels LV] ángeles FF, SG. Catalanismo (véase el Vocabulari s.v. àngels). El término se registra numerosas ocasiones en $L V$-poema no 1, 1e y $5 c$, no $34 b$ y $5 a$, etc. -. FF y $S G$ enmiendan con el término castellano, lección que requeriría, para respetar el patrón acentual del arte mayor, dos metaplasmos: sinalefa y dislocación acentual: «de_angéles». La lección primigenia angels, sin embargo, es perfectamente adecuada al patrón rítmico. Para más detalles sobre este locus véase apartado 1.2.

112 2f. lohando LV FF] loando SG. Interferencia grafemática aragonesa de $h$ expletiva, véase $D G R$ 1a y $1 \mathrm{~g}$. Se encuentran solo 3 casos en el CORDE, s. XV, en textos de rasgos aragoneses (documento notarial de los Reyes Católicos y Triunfo de amor). En el DiCCA-XV encontramos 4 variantes del lexema: loar (316), lohar (100), lloar (1) llohar (1). En el CICA no hay incidencias de la voz lohando o llohando, pero sí de lohar: de 32 casos 28 corresponden a textos valencianos. En el Vocabulari encontramos 5 casos de lohar, de los cuales 4 corresponden a Pero Martines, quien se relacionó con la corte de Aragón.

113 2g. cahí en el] cahía nel LV cahía n.el FF caía n'el SG. Se trata probablemente de una banalización del componedor, que lee "caía nel» en lugar de "caí en el», como debería ser dado el sentido del siguiente verso («levanteme presto»). Podría también tratarse de un error por cambio de tipo: el componedor toma la $a$ en lugar de la $e$. Sobre la $h$ expletiva, común en textos aragoneses, véase las notas a los versos $D G R$ 1a, 1g. En el DICCA-XV se registra caher y sus diversas conjugaciones en 165 ocasiones.

114 2j. claridat LV FF SG] Interferencia aragonesa, véase 1a.| li] aragonesismo o catalanismo, pronombre personal dativo de tercera persona singular. Véase Vocabulari s.v. li, Enguita Utrilla 1993: 127, Menéndez Pidal 1952: 252, Zamora Vicente 1985: 253 y Alvar 1958-1959: 227. En cuanto a la dificultad para dilucidar si se trata de una voz catalana o aragonesa, véase Giralt Latorre 2018: 16. | diere FF SG] dirce LV. Error mecánico por cambio de tipo, usual en el impreso, de $c$ por e (véase DGR 3b, $4 a, 5 e)$ y tipos trastocados, inversión entre $c(o e)$ y $r$. 


\author{
¡O, buenos ditxos del rey Salamón, ${ }^{115}$ \\ como la loha con gran devotión! ${ }^{116}$ \\ 25 De todo peccado la faze muy neta ${ }^{117}$ \\ y pone dolçor y grande 'legría. ${ }^{118}$ \\ $Y$ est'es la fuente de quien, cierto, mana ${ }^{119}$ \\ sabor y scientia, segund proffetía, 120
}

115 3c. ditxos LV FF SG] Interferencia grafemática del catalán. Véase ATF 1g.

116 3d. loha LV FF] loa SG. Interferencia grafemática aragonesa de $h$ expletiva, véase $D G R$ 1a, $1 \mathrm{~g}$ y ATF $2 f$. En el CORDE, s. $x V$, se registran 3 casos en el aragonés Libro del Tesoro de Girona. En el DiCCAXV hallamos más casos con la grafía - $h$ : loa (9), loha (16). En el Vocabulari solo se hallan 2 casos de lloha del valenciano March (s.v. Ilas y mesqui), igual que en el CICA (2 casos de los valencianos Ausiàs March y Jaume Roig). I devotión LV FF SG] Interferencia aragonesa a nivel grafemático. Según Alvar (1987: 37), el fonema /ŝ/, que en castellano medieval se ejecuta con la grafía ç, tiene una naturaleza doble de "oclusión seguida de fricación, algo como/ts/». En aragonés este fonema puede realizarse a través de las grafías ts o, en una simplificación gráfica, de una $t$ con valor de ç (Alvar, 1987: 37). En el CORDE sS. XV y XVI, solo se registran 12 casos de deuotion (ninguno de devotion): 10 en el Viaje de Juan de Mendevilla cuyo manuscrito se encuentra escrito en aragonés (Rodríguez Temperley 2006: 512); 2 en el Libro de refranes, del paremiólogo aragonés Pedro Vallés. En el CICA no se encuentra ninguna incidencia de devotion en el s. XV, mientras que devoción se registra 1 sola vez. Aunque la grafía $-t$ podría considerarse un cultismo, pareciera más económico postularla como aragonesismo, dado el sistema de interferencias observables en el resto de la composición.

117 3e. peccado LV FF] pecado SG. Se trata probablemente de una interferencia grafemática aragonesa, $c c$ con valor / $\mathrm{k} /$ (véase nota $D G R 1 \mathrm{~b}$ ), aunque no podría descartarse una interferencia del lexema catalán, dado que peccat es una realización formal muy usual (véase Vocabulari s.v. pecat/peccat). Nótese que las 26 ocasiones en que se utiliza el término peccat/s en $L V$, su realización es siempre con -cc, por lo cual podría deberse también a una regularización de Fenollar.

118 3f. dolçor LV FF SG] Catalanismo, véase el Vocabulari s.v. dolçor y CICA, con 215 registros. En el CORDE durante el siglo xV solo se encuentran 17 casos, en 6 documentos, la mayoría de filiación catalana o aragonesa, en contraste con los 289 del término dulçor. | 'legría] lagría LV, alegría FF, (a)legría SG. Conservamos la caída de vocal inicial pues puede ser una contracción por sinalefa o una interferencia aragonesa (véase verso $2 b$ ). Enmendamos, sí, el error por cambio de tipo $a$ por $e$.

119 3g. y est'es] y estes LV, y est.es FF, y ést(a) es SG. I quien FF SG] quie LV. Si bien se registra el pronombre qui en aragonés -véase Lapesa 1980: 495, Alvar 1958-1959: 227, Zamora Vicente 1985: 255, Enguita Utrilla 2009: 128 y Arnal Purroy \& Enguita Utrilla 1993: 64- y en catalán -véase Pompeu Fabra 2006: 58-66 y Lleal 2003: 56-, aquí la epéntesis parece un error mecánico, pues no se registra quie en ningún caso.

1203 h. scientia] scientia LV SG FF. Interferencia grafemática aragonesa, $t$ con valor de ç (véase nota a 3d). Aunque scientia podría considerarse un latinismo, la $t$ por ç actúa en numerosos términos castellanos del poema. En el CORDE, s. XV, scientia se registra en 65 casos, pero 48 se tratan de textos latinos. De 
y pone 'n las gentes sabidoría, ${ }^{121}$

y da salvatión por natura humana. ${ }^{122}$

IV

Los padres antigos aquesto sentid ${ }^{123}$

con grande alegría cantando el misterio.

O, Reyna, senyora, vienes de la vit ${ }^{124}$

d'aquell santo lassé do viene David, ${ }^{125}$

35 segund que lo cuenta en el su psalterio.

Tú de las virgens la perfectión, ${ }^{126}$

las 17 incidencias en contexto castellano, 12 (11 en el UV de Palencia y 1 en el Vocabulario de Santaella) se hallan en textos donde el latín se utiliza de manera general y, por tanto, tienen tendencia al cultismo. Los 5 casos restantes se encuentran en textos de rasgos aragoneses ( 2 documentos cancillerescos y 3 en el Cancionero de Estuñiga). Es de aclarar que en castellano la realización más usual era justamente sciencia, registrada en el CORDE en 534 ocasiones, frente a 186 de ciencia. En DICCA-XV se registran dos casos de scientia como variante formal de sciencia. I proffetía LV FF] profetía SG. Interferencia grafemática aragonesa - $f f$, véase nota DGR 2c. Respecto de la ejecución $t$ con valor de ç véase nota $3 \mathrm{~d}$. Nótese que en el CORDE no hay registros de las posibles variantes proffetia, proffeçia y profetia.

$1213 \mathrm{i}$. y pone ' $n$ las gentes FF] y ponen LV, y pon(e) en SG.

122 3j. salvatión LV FF SG] Interferencia aragonesa a nivel grafemático: grafía $t$ con valor /ŝ/. Véase nota $3 d$.

123 4a. antigos LV SG] antiguos FF. El uso de antigo/s está ampliamente registrado durante toda la Edad Media: en su forma singular en el CORDE tenemos 429 casos, mientras que en su forma plural se registran 910. Véase también el DME, s.v. antigo.

124 4c. senyora LV FF SG] Resulta difícil distinguir si es una interferencia catalana o aragonesa a nivel grafemático (ny con valor palatal $/ \mathrm{n} /$, véase nota 5e) o catalana a nivel léxico (véase Vocabulari s.v. senyor). | vit LV FF SG] Catalanismo léxico (véase el Vocabulari s.v. vit) o grafemático (véase nota a DGR 3i y ATF 1a). La ausencia de -t final en los términos en rima (sentid y David) nos inclinan a pensar que la interferencia probablemente se incorporó en la etapa de impresión.

125 4d. d'aquell] daquel LV, d·aquell FF, d'aquel(I) SG. Sobre el uso de // con valor / véase nota DGR 4d.

126 4f. virgens LV] vírgenes FF vírgen(e)s SG. Interferencia morfemática del plural catalán -ns (véase Giralt Latorre 2018: 15) que también se observa en el aragonés por apócope vocálica (Zamora Vicente 1985: 249). Desarrollamos la inadecuación de la enmienda de los editores anteriores en nuestro estudio, apartado 1.2. | perfectión LV FF SG] Interferencia grafemática del aragonés: uso de la grafía $t$ con valor / $\hat{s} /$ (véase nota ATF 3d). Aunque perfectión se registra en el s. XV en el CORDE ( 40 casos, frente a 502 de perfección), asumimos que la grafía - $t$ se trata de una interferencia dado que se repite en los términos en rima coronation y salvation, no registrados en el CORDE. 
tu grand claridad desfaze la niebla; tú eras digna de coronatión, ${ }^{127}$ pues sallió de ti la qual salvatión ${ }^{128}$

\section{$\mathrm{V}$}

Los santos prophetas, con grande victoria, de muy riquas perles bordan el su manto. ${ }^{130}$ Aquesta senyora más ganó la gloria, ${ }^{131}$ y ahun a las gentes es cosa notoria ${ }^{132}$ 45 que concebió d’Espírito Santo. ${ }^{133}$

127 4h. coronatión LV FF SG] Interferencia del aragonés a nivel grafemático ( $t$ con valor /ŝ/). Véase nota $4 \mathrm{f}$.

128 4i. sallió LV] sal·lió FF sal(I)ió SG. Interferencia a nivel grafemático del aragonés o el catalán. Véase nota DGR 4d.| salvatión LV FF SG] Misma interferencia grafemática aragonesa que en $4 \mathrm{f} \mathrm{y} 4 \mathrm{~h}$.

129 4j. d'escura] descura LV, de scura FF SG. Dado que el término escura se halla registrado en el CORDE, en el Vocabulari (con la variante scura), en el CICA y en $L V$ (poema no 5, 5b), consideramos que es más pertinente señalar la contracción vocálica en la preposición. | teniebla FF] tenibla LV teni(e)bla SG. Dada la rima en -ebla (niebla, 4g) parece evidente que el componedor omitió una e, por lo cual enmendamos. La voz tenibla, además, no se registra en el CORDE, mientras que la variante teniebla lo hace en 7 casos. Nótese que, a diferencia de DGR 4e y ATF 1a, aquí se mantiene el uso de l, lo cual es necesario por el término en rima niebla. Como se evidencia en el CORDE, este término oscilaba mucho en su grafía, también en las pretónicas: teniebla (7), teniebra (33), tiniebla (52), tiniebra (87). | sachó LV FF] sacó SG. Grafía -ch con valor /k/. Véase nota a DGR 2c.

$1305 \mathrm{~b}$. riquas $\mathrm{LV}$ ) riques $\mathrm{FF}$ ricas SG. Interferencia grafemática del aragonés ( $u$ superflua tras consonante velar /k/). Véase nota a DGR 1h. | bordan] brodan. Error mecánico, tipos trastocados. | perles LV FF SG] Catalanismo (Vocabulari s.v. perla). En catalán los plurales de las voces femeninas en a se realizan en es, véase Lleal 2003: 53 y Giralt Latorre 2018: 15. No hay incidencias en el CORDE de la voz perle/s.

131 5c. senyora LV FF SG] Interferencia aragonesa o catalana a nivel gráfemático o catalana a nivel léxico. Véase 4c.

132 5d. ahun LV FF] aún SG. Interferencia grafemática aragonesa de $h$ expletiva. Véase nota ATF $2 \mathrm{~g}$ y $D G R$ 6e.

133 5e. concebió LV FF SG] Aunque no es muy común, el pretérito de concebir con e pretónica se registra en el CORDE 16 veces ( 4 con esta realización y 12 con ç) en el s. Xv -5 pertenecen a la Crónica Troyana, texto de características aragonesas-. En DICCA-XV se registra 2 veces concebio y 11 conçibio. La variación del timbre vocálico es común en escribas castellanos (véase DGR 4e); en este caso puede también deberse a la influencia de la construcción verbal del aragonés: el tema de perfecto se modifica 
[f. 32v] Y est'es la guía de la salvatión ${ }^{134}$

de todos lohada los cherubines; ${ }^{135}$

esta, entre todas, la perfectión, ${ }^{136}$

muy sancta sabida con gran discretión, ${ }^{137}$

50 será por memoria fasta a los fines.

VI

\section{Tornada}

Muy sabio senyor, visrey espectable $\mathrm{e}^{138}$

de la senyoría del Rey d'Aragón,, 139

amado, fiel, justo, no mudable:

pues vos, causador del fecho notable,

55 la sempre lohada vos dé 'I gualardón.

por influjo analógico de las raíces del tema presente, como venió, sabiesen, sabió, havió. Véase Enguita Utrilla 2009: 14 y Zamora Vicente 1985: 275.

$1345 f$. salvatión LV FF SG] interferencia grafématica del aragonés ( $t$ con valor /ŝ/), que se repite en los términos en rima (perfectión y discretión). Véase nota $3 \mathrm{~d}$.

135 5g. lohada LV FF] loada SG. Interferencia grafemática aragonesa de $h$ expletiva, véase DGR 1a, $1 \mathrm{~g}$, ATF $2 \mathrm{f}$ y $3 \mathrm{~d}$. En el CORDE, s. $\mathrm{xV}$, encontramos 3 incidencias en el castellano aragonés de Triunfo de amor; en el CICA se registran 16 casos de lohada: 7 corresponden a LV, mientras que el resto corresponde a Dotzè del Crestià de Eiximenis - quien desarrolló su labor en la Corte de Aragón-, y a los valencianos Vita Christi (Isabel de Villena) y Proses mitològiques (Joan Roís de Corella). I cherubines LV FF] querubines SG.

136 5h. perfectión LV FF SG] Interferencia aragonesa a nivel grafemático. Véase nota anterior.

137 5i. discretión LV FF SG] Misma interferencia que en versos anteriores.

138 6a. Senyor LV FF SG] Puede tratarse de una interferencia catalana o aragonesa a nivel grafemático (ny) o catalana a nivel léxico (véase Vocabulari s.v. senyor y nota al verso 4c). | visrey LV FF SG] catalanismo (véase Vocabulari, s.v. visrey). De los 20 casos en los cuales este término aparece en el CORDE en la Edad Media, todos excepto uno pertenecen a textos aragoneses y/o catalanes. El término virrey, en cambio, se registra en el CORDE 109 casos. | espectable LV FF SG] catalanismo, véase Vocabulari s.v. espectable/spectable. En el CORDE se registra en solo dos textos: uno del aragonés García de Santa María y el otro un documento notarial de Fernando el Católico.

139 6b. senyoría LV FF SG] Interferencia grafemática (ny) o léxica (véase Vocabulari s.v. senyoria y nota 4c). 


\section{Bibliografía CITADA}

Abella SAMitier, Juan (2009), Selección de documentos de la villa aragonesa de Sos (1202-1533), Zaragoza, Institución Fernando el Católico.

AbizANDA y BRoto, Manuel (1915-1917), Documentos para la historia artística y literaria de Aragón procedentes del archivo de Protocolos de Zaragoza, siglo xVI, Zaragoza, Tip. La editorial Coso, 2 vols.

Alvar, Manuel (1958-1959), "Documentos de Jaca (1362-1502): estudio lingüístico», Archivo de Filología Aragonesa, 10-11, pp. 195-276.

ALvar, Manuel (1978), Estudios sobre el dialecto aragonés II, Zaragoza, Institución Fernando el Católico.

Alvar, Manuel (1987), "Grafías navarro aragonesas» en Estudios sobre el dialecto aragonés I, Zaragoza, Institución Fernando el Católico, pp. 13-46.

Alonso, Amado (1943), Castellano, español, idioma nacional. Historia espiritual de tres nombres, Buenos Aires, Losada.

Arnal Purroy, María Luisa, \& José María Enguita Utrilla (1993), «Aragonés y castellano en el ocaso de la Edad Media», Aragón en la Edad Media, 10-11, pp. 51-84.

Arnal Purroy, María Luisa, \& José María enguita Utrilla (1995), "La castellanización de Aragón a través de los textos de los siglos XV, XVI y XVII», Archivo de Filología aragonesa, 51, pp. 151-196.

BADIA I MARgARIT, Antoni (1981), La formació de la llengua catalana. Assaig d'interpretació histórica, Barcelona, Publicacions de l'Abadia de Montserrat.

BAEHR, Rudolf (1981), Manual de versificación española, Gredos, Madrid.

BALAGUER, Joaquín (1954), "Evolución del verso de arte mayor», en Apuntes para una historia prosódica de la métrica castellana, Madrid, CSIC, pp. 105-130.

BleCUA, Alberto (1983), Manual de crítica textual, Madrid, Castalia.

Beltran, Vicenç (2002), «Del cancioneiro al cancionero. Pero Vélez de Guevara, el último trovador» en Iberia cantat: estudios sobre poesía hispánica medieval, coord. Eva María Díaz Martínez y Juan Casas Rigall, Santiago de Compostela, Universidad de Santiago de Compostela, pp. 247-286.

CABEZUdo AStraIN, José (1961), "Los argenteros zaragozanos en los siglos XV y XVI», Seminario de Arte Aragonés, 10-12, pp. 181-202.

CANo AgUILAR, Rafael (1988), "La evolución del castellano medieval» en El español a través de los tiempos, Madrid, Arco Libros, pp. 193-220. 
CASANOVA, Emili (2011), "Influencia histórica del aragonés sobre el valenciano», Archivo de Filología Aragonesa, 67, pp. 201-235.

[CICA] Corpus informatizat del Català Antic, dir. Joan Torruella. http://cica.cat/ [consulta: 3/4/2021]

ClARKE, Dorothy C. (1942), "The copla real», Hispanic Review, 10/2, pp. 163-165. https://doi.org/10.2307/469502

Clarke, Dorothy C. (1949), "Imperfect Consonance and Acoustic Equivalence in Cancionero Verse», PMLA, 64/5, pp. 1114-1122. https://doi. org/10.2307/459553

CONDE, Juan-Carlos (2002), «Praxis ecdótica y teoría métrica: el caso del arte mayor castellano», La Corónica, 30/2, pp. 249-77. https://doi.org/10.1353/ cor.2002.0009

CONDE, Juan-Carlos (2016), "Poemas historiográficos: siglo XV» en Historia de la métrica medieval castellana, coord. Fernando Gómez Redondo, San Millán de la Cogolla, Cilengua, pp. 1023-1038.

ContINI, Gianfranco (1986), Breviario di Ecdotica, Milán-Nápoles, Riccardo Ricciardi.

[CORDE] Corpus Diacrónico del Español, Real Academia Española, Banco de datos [en línea]. http: corpus.rae.es/cordenet.html [consulta: 3/4/2021]

[DICCA-XV] LLEAL Coloma (dir.), Diccionario del siglo xv en la Corona de Aragón, http:// ghcl.ub.edu/diccaxv/home/index/myLanguage:es/ [consulta: 3/4/2021]

DISALVo, Santiago (2013), Los monjes de la Virgen: Representación y reelaboración de la cultura monacal en las cantigas de Santa María de Alfonso X, Newark, Juan de la Cuesta.

[DLC] Diccionari de la llengua catalana de l'Institut d'Estudis Catalans, Institut d'Estudis Catalans. https://dlc.iec.cat/ [consulta: 3/4/2021]

[DME] ALonso, Martín (1986), Diccionario Medieval español, Salamanca, Universidad Pontificia de Salamanca.

Duffel, Martin (1999), Modern Metrical Theory and the "Verso de Arte Mayor", Londres, Department of Hispanic Studies-Queen Mary and Westfield College.

DutToN, Brian (1990-1991), El cancionero del siglo xV (c. 1360-1520), Salamanca, Universidad de Salamanca, 7 vols.

ENGUITA UTRILLA, José María (2009), "Variedades internas del aragonés medieval», en Baxar para subir, colectánea de estudios en memoria de Tomás Buesa Oliver, 
coord. Vicente Langüés García, Zaragoza, Institución Fernando el Católico, pp. 111-149.

ESTEBAN LORENTE, Juan Francisco (1977), «La platería zaragozana en los siglos XIV y XV», Revista Príncipe de Viana. Homenaje a José María Lacarra, 3, pp. 331343.

FALCón PÉREZ, María Isabel (1999), "Los plateros zaragozanos en el siglo XV», Anuario de estudios medievales, 29, pp. 251-268. https://doi.org/10.3989/aem.1999. v29.i1.523

FERNÁNDEZ ORDóÑEZ, Inés (2002), "Tras la collatio o cómo establecer correctamente el error textual», La corónica, 30/2, pp. 105-180. https://doi.org/10.1353/ cor.2002.0004

FERRANDO FRANCÉS, Antoni (1982), «Un precedent del bilingüisme literari Valencià: La tertúlia d'Isabell Suaris a la València quatrecentista», Boletín de la Real Academia de Buenas Letras de Barcelona, 38, pp. 105-131.

FERRANDO FrANCÉs, Antoni (1983), "Certamen en "Lahors de la Verge Maria". València, 1474» en Els certàmens poètics valencians del segle XIV al XIX, Valencia, Institució Alfons el Magànim, pp. 166-219.

FERRANDo FrAncÉs, Antoni (1989), "La formació històrica del valencià», en Segon Congrés Internacional de la Llengua Catalana (1986). Àrea 7. Història de la Ilengua, ed. Ferrando Francés, Valencia, Institut Interuniversitari de Filologia Valenciana, p. 399-428.

FERRANDO FRANCÉS, Antoni (1999), «El paper del primers editors (1473-1523) en la fixació del català modern», Caplletra, 27, pp. 109-136.

FerRARESI, Alicia de (1974), "Locus amoenus y vergel visionario en Razón de Amor», Hispanic Review, 42/2, pp. 173-183. https://doi.org/10.2307/473060

FoulCHÉ-DelBOSC, Raymond (ed.) (1912), Cancionero castellano del siglo XV, Madrid, Bailly-Baillère, 2 vols.

FORT I CAÑELLAS, María Rosa (2002), «El català i l'aragonès, llenguas en contacte (Edat Mitjana i Moderna)», Caplletra, 32, pp. 111-125.

Frago Gracia, Juan Antonio (1991), «Determinación sociolingüística en la castellanización del Valle del Ebro» en I Curso sobre lengua y literatura en Aragón (Edad Media), Zaragoza, Institución Fernando el Católico, pp. 115132.

[GC] FABRA I POCH, Pompeu $\left(2006^{2}\right)$, Gramàtica catalana, Barcelona, Institut d'Estudis Catalans [edición facsimilar de la 7a ed., Barcelona, Institut d'Estudis Catalans, 1933]. 
[GEIEC] Gramàtica essensial della llengua catalana (2020), Barcelona, Institut d'Estudis Catalans. https://geiec.iec.cat/ [consulta: 3/4/2021]

GIRALT LATORRE, Javier (2018), «Aragonés y catalán en un libro de cuentas turolense del siglo XV» Revista de Filología Románica, 35, pp. 9-32. http://doi.org/10.5209/ RFRM.61680

Gómez Bravo, Ana María (1999), Repertorio métrico de la poesía cancioneril del siglo $x V$, Alcalá de Henares, Universidad de Alcalá de Henares. http://www.digitalhumanities.xyz/cancionero/ [consulta: 3/4/2021]

GómEZ REDondo, Fernando (2013), «El “adónico doblado” y el arte mayor», Revista de Literatura Medieval, 25, pp. 53-86.

GómEZ REDONDO, Fernando (2016), «El arte mayor y el adónico doblado» en Historia de la métrica medieval castellana, San Millán de la Cogolla, Cilengua, pp. 489502.

GómEZ REDondo, Fernando (2017), "La “vieja métrica” medieval: principios y fundamentos», Revista de Filología Española, XCVII/2, pp. 389-404.

GómEZ-FARGAS, Rosa María (1989), "Peculiaridades lingüísticas aragonesas en Triste deleytaçion", Archivo de Filología Aragonesa, 42-43, pp. 21-64.

GUARNER, Luis (1974), Les trobes en lahors de la Verge Maria. Primer incunable español, Valencia, Patronato Nacional del V Centenario de la Imprenta.

IGUAL ÚBEDA, Antonio (1956), El gremio de plateros (ensayo de una historia de la platería valenciana), Valencia, Institución Alfonso el Magnánimo, 1956.

KASTEN, Lloyd, \& Cody FLORIAN (2001), Tentative Dictionary of Medieval Spanish, New York, The Hispanic Seminary of Medieval Studies.

LAPESA, Rafael (1980), Historia de la lengua española, Madrid, Gredos.

LÁZARO CARRETER, Fernando (1972), "La poética del arte mayor castellano», en Studia hispanica in honorem Rafael Lapesa, Madrid, Gredos-Cátedra, pp. 243-278.

LÁzARo MorA, Fernando (1978-1980), «RL > LL en la lengua literaria», Revista de Filología Española, vol. 60, 1-4, pp. 267-283. https://doi.org/10.3989/ rfe.1980.v60.i1/4.649

LLEAL, Coloma (2017²), Breu història de la llengua catalana, Titivillus (edición digital) [1 ${ }^{\text {a }}$ ed.: Barcelona, Barcanova, 2003].

Martí Grajales, Francisco (1894), "Advertencia del editor», en Primer libro impreso en España. Les trobes en lahors de la Verge Maria, publicadas en Valencia en 1474 y reimpresas por primera vez, Valencia, Librería de Pascul Aguilar, pp. 16-91. 
MARTINES, Josep (2002), "L'aragonés i el lèxic valencià, una aproximaciò», Caplletra, 32 , pp. 157-201.

MARTínez VINAT, Juan (2018), Cofradías y oficios. Entre la acción confraternal y la organización corporativa en la Valencia medieval (1238-1516), Valencia, Universitat de València [tesis doctoral].

MARTOS, Josep Lluís (2013), "Variantes y variaciones interpoemáticas: de la Vida de la sacratíssima Verge Maria a la Lahor de la Verge de Joan Roís de Corella», Revista de Literatura Medieval, 25, pp. 135-164.

MARTOS, Josep Lluís (ed.) (2017), Variación y testimonio único. La reescritura de la poesía, Alicante, Universitat d'Alacant.

MARTOS, Josep Lluís (2021), "Les trobes en lahors de la verge Maria: historiografía de un incunable poético ¿sine notis?», Criticón, 141, pp. 15-36 [consulta: 14/12/2021]. https://doi.org/10.4000/criticon.18914

MATEO PAlAcios, Ana (2014), «Aragonesismos y catalanismos en la traducción castellana realizada por Gonzalo García de Santa María de Las vidas de los sanctos religiosos de Egipto", Archivo de Filología Aragonesa, 70, pp. 87-114.

MENÉndez PIDAL, Ramón (1952), Manual de gramática histórica española, Madrid, Espasa-Calpe.

Mettmann, Walter (ed.) (1988), Alfonso X, el Sabio, Cantigas de Santa Maria, Madrid, Castalia, 2 vols.

Migne, Jacques-Paul (ed.) (1844-1855), Patrologia Latina, Paris, ed. ChadwyckHealey (1996-2001), Patrologia Latina Database. http://patristica.net/latina/ [consulta: 3/4/2021].

MolL, Francesc de B. $\left(2006^{2}\right)$, Gramàtica històrica catalana, Valencia, Publicacions de la Universitat de València [1a ed.: Madrid, Gredos, 1952].

NAVARRo Tomás, Tomás (1956), Métrica Española, New York, SUP.

OLIVA, Salvador (1986), Introducció a la métrica, Barcelona, Quaderns Crema.

PARRAMON I BLASCO, Jordi (1992), Repertori mètric de la poesia catalana medieval, Barcelona, Abadia de Montserrat.

PARRILLA, Carmen (2017), «Algunos aspectos de variación textual en la poesía contenida en El Grimalte y Gadissa de Juan de Flores», en Variación y testimonio único, la reescritura de la poesía, coord. Josep Lluís Martos, Alicante, Universitat d'Alacant, pp. 253-269. 
PÉREZ BOSCH, Estela (2005), «Algunos casos de bilingüismo castellano catalán en el Cancionero general de 1511. Propuesta de aproximación histórica y literaria», en Actas del IX Congreso Internacional de la Asociación Hispánica de Literatura Medieval, A Coruña, Toxosoutos, pp. 355-370.

PÉrEz BosCH, Estela (2009), Los valencianos del «Cancionero General»: estudio de sus poesías, Valencia, Universitat de València.

Pérez Priego, Miguel Ángel (ed.) (1989), Juan de Mena, Obras Completas, Barcelona, Planeta.

Pérez Priego, Miguel Ángel (ed.) (1991), Marqués de Santillana, Poesías Completas, Madrid, Alhambra, 2 vols.

Pérez Priego, Miguel Ángel (1997), La edición de textos, Madrid, Síntesis.

PÉREZ Priego, Miguel Ángel (2012), «Los testimonios únicos en la edición de textos medievales» en Rumbos del hispanismo en el umbral del Cincuentenario de la AlH, coord. Patrizia Botta, et al., Roma, Bagatto Libri, 2 vols., pp. 425-430.

POTTIER, Bernard (1986), "La evolución de la lengua aragonesa a fines de la Edad Media», Archivo de Filología Aragonesa, 38, pp. 225-240.

RAULIN, Jean (1516), "In Nativitate domini», en Opus sermonum de Adventu, Paris, Berthold Rembolt [USTC 144618].

REYES GómEZ, Fermín de los (2005), "Segovia y los orígenes de la imprenta española», Revista General de Información y Documentación, 15/1, pp. 123-148

REYES GómEZ, Fermín de los (2015), La imprenta incunable, el nuevo arte maravilloso de escribir, Madrid, Consejo Superior de Investigaciones Científicas.

ROdRíGUEZ TEMPERLEY, María Mercedes (2006), «Imprenta y variación textual: el caso de Juan de Mandevilla», Incipit, 25, 511-522.

Ross, Jill (2008), "The Metaphorics of Mary: Language and Embodiment in Berceo's Milagros de Nuestra Señora» en Figuring the Feminine: The Rhetoric of Female Embodiment in Medieval Hispanic Literature, Toronto, University of Toronto Press, pp. 108-251. https://doi.org/10.3138/9781442688100-006

Rubio Vela, Agustín (2020), Los Castellví en la Baja Edad Media valenciana. Generaciones y semblanzas de un linaje, Valencia, Gráficas Papallona.

SANCHIS GuARner, Manuel (ed.) (1974), Les trobes en lahors de la Verge Maria (València, 1474), Valencia, Caixa d'Estalvis i Mont de Pietat de València.

SANCHIS GUARneR, Manuel (ed.) (1979), Les trobes en lahors de la Verge Maria, Valencia, Vicent García Editors S.A. 
SANCHIS SIVERA, José (1922), "La orfebrería valenciana en la Edad Media», Revista de Archivos, Bibliotecas y Museos, 26/4, pp. 1-17, 235-259 y 612-637.

SANCHIS SiVERA, José (1923), "La orfebrería valenciana en la Edad Media [conclusión]", Revista de Archivos, Bibliotecas y Museos, 17, pp. 34-55 y 186203.

Salvador Miguel, Nicasio (ed.) (1987), El Cancionero de Estúñiga, Madrid, Alhambra. SEGRE, Cesare (1979), "Critica testuale, teoria degli insiemi e diasistema», en Semiotica Filologica. Testo e modelli culturali, Torino, Einaudi, pp. 53-64.

SERRA I BALDó, Alfons (1932), Resum de poetica catalana (Mètrica i versificació), Barcelona, Editorial Barcino.

TWOMEY, Lesley (2008), The Serpent and the Rose. The Immaculate Conception and Hispanic Poetry in the Late Medieval Period, Leiden/Boston, Brill. https://doi. org/10.1163/ej.9789004165953.i-314

VAlero Moreno, Juan Miguel (2016), «Las formas estróficas» en Historia de la Métrica castellana, coord. Fernando Gómez Redondo, Cilengua, San Millán de la Cogolla, pp. 502-540.

VIDAL GonZÁlez, Francisco (ed.) (2003), Cancionero, Madrid, Cátedra.

[VOCABULARI] COLÓN I DOMÈnECH, Germà (dir.), Vocabulari de la Llengua Catalana Medieval de Lluís Faraudo de Saint-Germain, Institut d'Estudis Catalans. https://www.iec.cat/faraudo/ [consulta: 3/4/2021]

ZAMORA VICENTE, Alonso (1985), "Aragonés», en Dialectología española, Madrid, Gredos, pp. 211-286. 